\title{
THE RIGHT OF STATES TO REGULATE IN RISK-AVERSE AREAS AND THE ECtHR CONCEPT OF MARGIN OF APPRECIATION IN THE WTO US-COOL ARTICLE 21.5 DECISION
}

\begin{abstract}
Anna Aseeva*
Summary: This paper aims to explore the constituent grammars of the margin of appreciation as a concept, and the way it is used by world trade judges, as well as the reasons for, and the immediate and potential outcomes directly and indirectly arising from, the plea to the concept when deciding WTO disputes relating to domestic societal regulation. In doing so, it is particularly important to demonstrate, through a detailed analysis of GATT and WTO jurisprudence, that GATT/WTO judges have applied the necessity test in order to follow different political agendas at different times - and also using the necessity narrative in various ways, including the hypothetical aim to 'discipline' members to regulate in the least trade-restrictive way possible. Until the US-COOL Article 21.5 decision, under the TBT, world trade adjudicators, and especially the Appellate Body, added nuances to the necessity test with considerations related to the right of WTO members to regulate in order to set their own level of protection. The latest relevant interpretative development in US-COOL Article 21.5, namely the WTO Appellate Body's plea for the margin of appreciation concept, may have interesting implications for future WTO jurisprudence. At least two scenarios are possible. Either the Appellate Body has tacitly suggested in this ruling that members have certain discretion in considering what could constitute a legitimate objective of a particular regulation. Or the Appellate Body's interpretation implies that the permissible degree of regulatory discretion of members actually rather depends on the importance of the objective to a member, and not - or to a lesser extent - on its legitimacy, so the latter should not be placed under strict scrutiny.
\end{abstract}

\section{Introduction}

The rationale for WTO legal disciplines applying to risk-related issues is to deliver a legal framework for state regulations promoting the

\footnotetext{
Adjunct lecturer in EU law, HEC Paris, Tax and Law Department. Postdoctoral researcher, Project CNRS (Le Centre national de la recherche scientifique/French National Fund of Scientific Research) 'International Investment Law and Natural Resources'. I wish to thank all organisers and participants of the $13^{\text {th }}$ Jean Monnet Seminar 'EU Law and Risk Regulation', 19-25 April 2015, Dubrovnik. Views and errors are mine. Comments and suggestions are most welcome at anna.aseeva@graduateinstitute.ch.
} 
protection of human and plant life and health, the prevention of deceptive practices, the protection of the environment, etc, that can potentially affect transboundary trade. It is argued that gradually traders have to face barriers resulting from such domestic regulations, particularly because different societies are not evenly risk averse. ${ }^{1}$ On the other hand, such societal matters as public health and the environment are areas where the regulatory process goes hand in hand with technical innovation. That is, regulation at the domestic level is increasingly affected by efficiency concerns, such as necessity, scientific justification, procedural legitimacy, and consistency, resulting from a wide range of influences, ranging from the pressure of internal lobbies to coordination at the international level through the creation of international standards. ${ }^{2}$

The fact that some WTO disciplines are designed to strike a delicate balance between free trade and domestic regulatory autonomy pushed the WTO to the first row of key players in the global debate about risks. These disciplines are the WTO Sanitary and Phytosanitary Measures (SPS) and Technical Barriers to Trade (TBT) Agreements. The SPS covers measures necessary to protect human, animal or plant life or health from risks related to food and agricultural products. The TBT applies to the protection of the following: human safety or health; the prevention of deceptive practices; the protection of plant life or health; and the protection of the environment. ${ }^{3}$ Other objectives may include quality (eg requiring that vegetables and fruits reach a certain size to be marketable), technical harmonisation (eg harmonising certain sectors, such as telecommunications), or trade facilitation (eg harmonising customs equipment). ${ }^{4}$

One of the central tools of SPS/TBT regimes is the assessment of the creation and design of regulations related to risks. While the SPS has been tested in practice by WTO judges since the 1990s, the TBT was, until very recently, a rather 'dormant' WTO agreement, and was interpreted only once - in 2002. Since 2012, however, a few disputes have reached the stage of appeal and have been settled by WTO adjudicators. Therefore, as the SPS case law has been discussed at length since the late 1990s, in this article I will focus on the TBT regime and case law. While I will sketch all the cases decided under the TBT, I will pay very particular attention to the rulings of WTO tribunals in the most recent case, US-

\footnotetext{
1 In this sense, see eg P Mavroidis, G Bermann, and M Wu, The Law of the World Trade Organization (WTO): Documents, Cases and Analysis (West Law School 2010) 262-263.

2 BM Hoekman and MM Kostecki, The Political Economy of the World Trading System: The WTO and Beyond (OUP 1999) 462-465; A Lang, World Trade Law after Neoliberalism (CUP 2011) 159; Mavroidis, Bermann and Wu (n 1) 263.

3 WTO, 'Technical Information on Technical Barriers to Trade' <http://www.wto.org/ english/tratop_e/tbt_e/tbt_info_e.htm> accessed 11 October 2015; A Guzman and J Pauwelyn, International Trade Law (Aspen Publishers 2009) 523.

4 ibid.
} 
COOL Article 21.5. Namely, in this case, world trade judges, especially the Appellate Body, when assessing the conflicting regulation, possibly tried to lean towards a strict proportionality test instead of the more traditional GATT/WTO necessity analysis. The latter implies ranking in favour of values of free trade and market competition while still recognising the states' right to regulate.

In this reasoning, WTO judges in particular raised, among other things, the concept of margin of appreciation - an approach known in domestic administrative law along with proportionality stricto sensu, used and developed at the international level by the European Court of Human Rights (hereinafter: ECtHR, the Court). At the level of the European Convention on Human Rights, the margin of appreciation refers to some latitude of deference or error which the Strasbourg organs will allow to national legislative, executive, administrative and judicial bodies'. ${ }^{5}$

The European Convention on Human Rights (hereinafter: the Convention) provides for a collective remedy that allows individuals to file an administrative appeal before the Court in Strasbourg in cases of a violation of the Convention and/or its additional protocols by a member state of the Convention. ${ }^{6}$ By ratifying the Convention, a state undertakes the obligation under its Article 1 'to secure to everyone within their jurisdiction' a set of rights and freedoms enshrined in the subsequent 18 articles (Section I) plus those other rights and freedoms contained in Protocols 1 , 4, 6 and 7, as amended by Protocol 11, should it decide to ratify them as well. ${ }^{7}$ The decisions of the ECtHR are binding on the contracting parties of the Convention. ${ }^{8}$ More recently, the margin of appreciation has been re-affirmed in the text of the Convention's Preamble as follows:
Affirming that the High Contracting Parties, in accordance with the principle of subsidiarity, have the primary responsi- bility to secure the rights and freedoms defined in this Con- vention and the Protocols thereto, and that in doing so they enjoy a margin of appreciation, subject to the supervisory jurisdiction of the European Court of Human Rights estab- lished by this Convention. ${ }^{9}$

\footnotetext{
5 HC Yourow, The Margin of Appreciation Doctrine in the Dynamics of European Human Rights Jurisprudence (Martinus Nijhoff 1996). See also European Court of Human Rights, 'Application No 176/56 (Greece v United Kingdom, or the “Cyprus” case)' (1958-1959) 2 Yearbook of the European Convention on Human Rights, 174, 176.

6 Council of Europe, 'The European Convention on Human Rights' <http://www.coe. int/en/web/conventions/full-list/-/conventions/treaty/005 >; European Court of Human Rights, 'The Court: General Presentation: How the Court Works'<http:/ /www.echr.coe.int/ Pages / home.aspx?p=court/howitworks\&c=\#newComponent_1346158325959_pointer> accessed 29 May 2015.

7 ibid.

8 ibid.

9 Protocol 15 to the Convention, adopted on 24 June 2013.
} 
In this article, I argue that there are embedded knowledge structures of specific WTO reasoning applying to societal regulation disputes that influence judicial decision-making in a very interesting way. In particular, until May 2015 when the WTO Appellate Body issued its ruling on US-COOL Article 21.5, world trade judges had never applied a strict proportionality test that the concept of margin of appreciation maps on, as the ECtHR would do that. Namely, the latter unambiguously balances the state measures in question against the objective pursued.

Before May 2015, the concept of margin of appreciation had not even once been explicitly applied or referred to within GATT/WTO litigation. ${ }^{10}$ Oftentimes under the GATT, ${ }^{11}$ and under the TBT, ${ }^{12}$ while between two sets of values, trade values were ranked higher, the respect of other non-trade - values of a defendant was deemed violating WTO law, but often necessary - especially in recent TBT jurisprudence. This does not correspond to a strict proportionality analysis. While proportionality stricto sensu relates to the proportionality of the means related to the ends, and the balancing between two values of equal footing, the necessity test means that the footing is a priori fixed in favour of one value. The concept of margin of appreciation, however, requires the strict proportionality test and a proper balancing exercise. The WTO adjudicators usually do not expressly acknowledge or state that they balance a national measure deemed trade-restrictive against the objective pursued by that measure.

In the first part of the article, I will track the main highlights of the ECHR regime, which are the most relevant for the margin of appreciation conceptualisation and interpretation. In the second part, I will briefly introduce the GATT/WTO relevant legislative and jurisprudential developments. In the third part, I will primarily sketch the fundamentals and relevant developments of the TBT framework. In the fourth part, I discuss the decisions in cases that have fully involved the TBT. I will address one, some or all of them (together with previous relevant disputes where needed) for each special issue that I consider important for the overall analy-

10 The concept was never applied, but just mentioned in the following rulings: US-Measures Affecting the Cross-Border Supply of Gambling and Betting Services: Arbitration Report (21 December 2007) DS285, paras 4.16-18; EC-Regime for the Importation, Sale and Distribution of Bananas III: Arbitration Report (24 March 2000) DS27, para 52; US-Tax Treatment of Foreign Sales Corporations: Arbitration Report (30 August 2002) DS108 para 5.

11 See eg Brazil - Measures Affecting Imports of Retreaded Tyres [Brazil-Tyres]: Report of the Appellate Body (3 December 2007) DS332; European Communities - Measures Affecting Asbestos and Products Containing Asbestos [EC-Asbestos]: Report of the Appellate Body (12 March 2001) DS135.

12 See eg United States - Measures Affecting the Production and Sale of Clove Cigarettes [USClove Cigarettes]: Report of the Appellate Body (4 April 2012) DS406; United States - Measures Concerning the Importation, Marketing and Sale of Tuna and Tuna Products [US-Tuna II (Mexico)]: Report of the Appellate Body (16 May 2012) DS381; United States - Certain Country of Original Labelling (COOL) Requirements - Recourse to Article 21.5 of the DSU by Canada and Mexico [US-COOL Article 21.5]: Report of the Appellate Body (18 May 2015) DS384 and 386. 
sis. The highlighted issues are especially, but not exclusively, various interpretive and normative considerations regarding non-discrimination and necessity under the TBT. The last part draws general conclusions.

The aim of this article should not be misunderstood. I do not seek to call for the ECtHR to cite or rely on WTO jurisprudence, or the other way around (the latter is quasi-impossible in any case, for reasons which will be exposed later, especially in the section on WTO dispute settlement essentials.) Neither do I call for WTO tribunals to use the ECtHR interpretive approaches and principles, or vice versa. What I primarily intend to do here is to expose interesting similarities between the ECtHR's general use of the concept of margin of appreciation, and the related test of proportionality stricto sensu, and the WTO appeal tribunals' - surprising - reasoning expressly invoking the margin of appreciation in its last ruling under the TBT; and, more generally, I seek to display the growing discursive tendency of WTO judges to underline deference to domestic regulators under the TBT, which is drawing somewhat closer to the concept of margin of appreciation. The reason I do not make a parallel with the domestic administrative law of basically any Continental jurisdiction is because the WTO is beyond the level of state law. At this level, it is especially - but not exclusively - the Strasbourg Court that has developed the notion of margin of appreciation into a fully fledged concept which is most often used in its jurisprudence.

\section{European Convention on Human Rights regime}

\subsection{Main highlights related to the ECtHR's use of margin of appreciation}

Full explanations of the fundamentals of the European Court of Human Rights regime have been extensively narrated elsewhere, and there is no need for me to do more than just briefly overview the main highlights that may directly relate to the subject of this article.

One of the main concepts is the principle of subsidiarity, and its particular workings in the ECHR regime. Since its inception, the ECHR has been based on the idea that it is primarily its member states that are responsible for respecting and enforcing the Convention. Recall that the 'margin of appreciation' (MoA) means the room for manoeuvre that a supra-national organ such as the ECtHR may grant to state authorities in fulfilling their obligations under relevant supra-national instruments. Basically, this means that national authorities, in securing the rights and freedoms defined in the Convention, should themselves decide democratically what is appropriate for their nation. ${ }^{13}$ The general con-

13 S Greer, The Margin of Appreciation: Interpretation and Discretion under the European Convention on Human Rights (Council of Europe Publishing 2000) 5-6. 
ception of MoA is thus analogous to the principle of subsidiarity that is especially characteristic of the field of European Union law. The principle of subsidiarity within the ECHR regime requires that the Strasbourg Court intervenes only when the highest court of appeal in the concerned member state has not ensured the application of the Convention, or did so incompletely. ${ }^{14}$

I continue with the concept of pilot judgments of the ECHR, as, from a particular standpoint, it is an important stepping stone to the actual implementation of the principle of subsidiarity in the European regime of human rights. In the pilot-judgment scheme, the Strasbourg Court provides the concerned state - in addition to the verdict - with clear guidance on how to eliminate the malfunction that has been judged by the ECHR as the cause of the violation. ${ }^{15}$ This procedure takes place only when the Court receives a significant number of requests from one and the same state arising from one and the same cause, thus being a product of structural problems within the member in question. ${ }^{16}$ Note this procedure, as it will be relevant to understand the later reasoning regarding the operation of the WTO law regime, and the overall analysis.

It is important to stress here that passing a judgment and transmitting relevant guidance on how to comply with the Convention is one thing, while actually bringing the state in question into compliance is a totally different one. As an example, it has been several years since the Court issued its first pilot opinion against the UK on the problem of the right of prisoners to vote. ${ }^{17}$ Nothing, however, was undertaken by the UK regarding the judgment and the subsequent instructions of the ECtHR. The Committee of Ministers of the Council of Europe even officially called on the British government to implement the related decision of the Court. ${ }^{18}$ However, this call to order was ignored by the UK. And it was only then that the ECtHR made a clear point by issuing a new pilot judgment (Greens and MT $v$ the United Kingdom), giving London six months to comply with the decision to grant prisoners voting rights guaranteed by the Convention.

Coming back to my view above that the pilot-judgment procedure is important for the effectiveness of subsidiarity in the ECHR regime,

\footnotetext{
14 ibid.

15 European Court of Human Rights, 'The Pilot-Judgment Procedure' (Information note issued by the Registrar 2009) <http://www.echr.coe.int/Documents/Pilot_judgment_procedure_ENG.pdf> accessed 29 May 2015.

16 ibid.

17 European Court of Human Rights, 'Prisoner's Right to Vote' (Press Unit Factsheet, February 2015) <http://www.echr.coe.int/Documents/FS_Prisoners_vote_ENG.pdf> accessed 29 May 2015.

18 ibid.
} 
if some consider that this scheme intrudes on the policy space of the member states (because the latter are supposed to freely apply the judgments of the Court, for example), ${ }^{19}$ it can still ensure both the actual involvement and strengthening of national courts, thus reinforcing subsidiarity. Note that the Secretary General of the Council of Europe, Thorbjørn Jagland, insisted that the pilot-judgment system, in forming part of the broader reform of the Court, gave states the means to manage by themselves violations committed, so that many cases would not need to reach Strasbourg. ${ }^{20}$ Similar applications can be deferred until the pilot judgment in question is implemented. Many applicants now obtain compensation more speedily because remedies are found at national level. ${ }^{21}$

The first pilot-judgment intervention concerned the Broniowski $v$ Poland row and related cases. ${ }^{22}$ This row was brought to a successful conclusion following the indications that were issued by the ECtHR, and the remedies that were introduced. Hence, new legislation was passed and pending cases were resolved. ${ }^{23}$

After a glimpse at the statistics, one cannot in any case help but agree with Jagland on the pragmatic aspects of the pilot-judgment scheme and its positive effects on subsidiarity. The Council of Europe's 2011 statistics indicate that the number of judgments of the Court fully implemented by the contracting states has increased by almost $80 \%$ compared to 2010 (the year of the reform of the Strasbourg Court). ${ }^{24}$ For the first time in ten years, the number of new cases filed has even decreased. ${ }^{25}$

Now I move directly to the concept of MoA as developed by the ECtHR - in pilot-judgments - as well as the regular procedure. In this regime, for each case treated, the Strasbourg Court must determine the flexibility, or discretion, that the member states have, regarding one or another hu-

19 B Pfiffner and S Bollinger, 'Ausufernde Interpretation der Menschenrechte' Neue $\mathrm{Zu}$ ercher Zeitung (Zürich 2 February 2012) <http://epaper.nzz.ch/nzz/forms/page.htm> accessed 29 May 2015.

20 Human Rights Europe, 'Jagland: Human Rights Are Not Getting "Out of Hand"' (Council of Europe 16 February 2012) <http://www.humanrightseurope.org/2012/02/jaglandhuman-rights-are-not-\%E2\%80\%9Cgetting-out-of-hand\%E2\%80\%9D/> accessed19 May 2015.

21 ibid.

22 The so-called Bug River cases: see eg Broniowskiv Poland [GC] App no 31443/96 (ECHR 2004-V). See also Broniowski v Poland (friendly settlement) [GC] App no 31443/96 (ECHR 2005-IX).

23 See EG v Poland App no 50425/99 and 175 other Bug River Applications (ECHR 23 September 2008).

24 Council of Europe, 'Execution of Strasbourg Court Judgments: Considerable Progress But Concern About Major Structural Problems' (Press Release DC042, 2012) < https:/ /wcd. coe.int/ViewDoc.jsp?Ref=DC-PR042(2012)\&Language $=$ lanEnglish\&Ver=original\&Site $=\mathrm{CO}$ E\&BackColorInternet=F5CA75\&BackColorIntranet=F5CA75\&BackColorLogged=A9BACE $>$ accessed 19 May 2015.

25 ibid. 
man rights issue. In other words, the extent to which a member's deviation from or restriction of a right guaranteed by the Convention is 'acceptable' given that it is covered by the discretion of states, understood as a margin of appreciation for national authorities in the implementation of certain obligations put upon them under the ECHR. ${ }^{26}$

This approach of Strasbourg shows that the Court leaves a wide MoA to states on some delicate social issues (mostly of the Western European system of values, though), such as abortion, the status of the embryo, or the presence of crucifixes in classrooms. ${ }^{27}$ However, it could be presumed that it is more restrictive regarding respect of certain human rights than others, as could be seen in the recent decision on the deportation of a foreign criminal, for example. ${ }^{28}$ On the other hand, this dividing line may be seen as the Strasbourg Court's different level of strictness depending on the kind of interest of certain member states - eg national security issues in the above case on deportation. It also appears more restrictive in practice, even if never officially spelled out, regarding non-Europeancentric values, such as decisions on religious symbols and clothing - eg the wearing of extra-Occidental religious symbols and clothing in education institutions. ${ }^{29}$

The assessment of MoA represents a sort of a compromise, as it appears to primarily depend on the weighing of the importance of the interests of parties to the Convention, and of rights protected by the ECHR. As already mentioned, the proportionality test stricto sensu is about appreciating the proportionality of the means chosen and the legitimate objective that is pursued, and the balancing between two values where either one can potentially be ranked higher than the other. That is, while the Court assesses the extent to which a deviation from a provision of the ECHR is justifiable, the provisions of the Convention themselves obviously do not vary.

Notably, while the pilot-judgment scheme is a relatively recent ECtHR practice, it is from its first judgments that the Court introduced the principle of subsidiarity inherent in the European mechanism for the protection of human rights and recognising that member states have a margin of appreciation in how they implement the rights laid down in

\footnotetext{
26 See eg Greer (n 13) 4-7.

${ }^{27}$ RR v Poland App no 27617/04 (ECHR 26 May 2011); Chamber judgment, Costa and Pavan v Italy App no 54270/10 (ECHR 28 August 2012); Chamber judgment Lautsi et al $v$ Italy App no 30814/06 (ECGR 18 March 2011).

28 See eg Omar Othman v United Kingdom App no 8139/09 (ECHR17 January 2012). See also, generally, E Brems (ed), Conflicts Between Fundamental Rights (Intersentia 2008).

29 I am not even talking about the Court's recent decision regarding the French full veil ban, that is, SAS v France, App no 43835/11 (ECHR 1 July 2014). Here the cases that come to mind are: Dahlab v Switzerland, 15 February 2001; and especially Mann Singh v France, 27 November 2008.
} 
the Convention. Yet, in 1968, it ruled that the ECtHR cannot and should not replace relevant national authorities - otherwise, the subsidiary nature of the international mechanism of the collective guarantee of human rights established by the Convention would be lost. ${ }^{30}$ Therefore, national authorities remain free to choose the measures they consider appropriate in the areas governed by the Convention - the Court's supervision covers only the conformity of these measures with the requirements of the Convention. ${ }^{31}$

A few years later, the Strasbourg Court noted that not only is the machinery of protection established by the Convention subsidiary to the national systems safeguarding human rights systems, but also, and especially, it is primarily a matter for each member state to ensure enjoyment of the rights and freedoms the Convention enshrines. ${ }^{32}$ The institutions created by it must contribute in their way, too, but they should become involved only through contentious proceedings and after full exhaustion of domestic remedies pursuant to Article 26 of the Convention. ${ }^{33}$

These considerations led the ECtHR to recognise that states have an MoA in many areas. In a more recent judgment regarding religious signs in public places, the Court, for instance, held that, as long as it was not part of a form of indoctrination, and given the lack of European consensus on this issue, the choice of putting crucifixes in classrooms in Italy remains within the MoA of the latter. ${ }^{34}$

\subsection{Margin of appreciation: synopsis of the concept}

In terms of the legal nature of the notion of 'margin of appreciation', lawyers - practitioners and academics alike - distinguish between the concept, the legal principle, and the doctrine of the margin of appreciation. The doctrine of margin of appreciation generally refers to the national margin of appreciation, representing a defined set of principles, and means the margin of appreciation that normally only states can benefit from. ${ }^{35}$ In relation to this, the principle of margin of appreciation refers to

\footnotetext{
30 'The Court points out that the machinery of protection established by the Convention is subsidiary to the national systems safeguarding human rights'. Case 'Relating to Certain Aspects of the Laws on the Use of Languages in Education in Belgium' $v$ Belgium (Belgian Linguistic case) App no 1474/62, 1677/62, 1691/62, 1769/63, 1994/63, 2126/64, §10 (ECHR 1968) para 10.

31 ibid.

32 Handyside $v$ The United Kingdom App no 5493/72 (ECHR 7 December 1976) para 48.

33 ibid.

34 ECtHR, Lautsi et al $v$ Italy

35 S El Boudouhi, 'A Comparative Approach of the National Margin of Appreciation Doctrine Before the ECtHR, Investment Tribunals and WTO Dispute Settlement Bodies' (April 2015) Robert Schuman Centre for Advanced Studies Research Paper No RSCAS 2015/27, $1<$ http://ssrn.com/abstract=2625625> accessed 5 July 2015. See also J Kratochvil, 'The
} 
a material legal rule with a defined legal content, proper for national legal systems. ${ }^{36}$ The concept of margin of appreciation can be seen as an idea of discretion or scope of manoeuvre from which states, as well as actors inside or beyond states, may benefit. ${ }^{37}$ Seen as a concept, margin of appreciation is then not necessarily 'national', and can also have far greater normative flexibility. ${ }^{38}$ Hence, for reasons of expediency, in this paper I will use the term 'concept' with relation to margin of appreciation.

The concept of margin of appreciation (Fr marge d'appréciation) has been used in different legal configurations. As a specific notion of administrative law, margin of appreciation has been extensively used by the French Conseil d'Etat ('State Council'), as well as by the German Bundesverwaltungsgericht ('Supreme Administrative Court'), but the equivalent legal basis of this concept of administrative discretion can be found in every jurisdiction of the civil, or continental, law system. ${ }^{39}$ In Germany, margin of appreciation may also refer to the freedom of parliament in assessing, for example, a situation with regards to national objectives - ie, the legislative branch enjoys wide discretion in how to advance the objectives that still form part of written laws and regulations. ${ }^{40}$

As stated in the introduction, at the level beyond the state, one of the first recourses to the MoA concept occurred in 1956 in the case law of the ECtHR. ${ }^{41}$ Since then, recourse to the concept of MoA has become a stable, essential and characteristic practice of the Court. ${ }^{42}$ Interpretive criteria have developed during the application of MoA, as have special principles related to them which will be discussed in the sections that follow.

Inflation of the Margin of Appreciation by the European Court of Human Rights' (2011) 29(3) Netherlands Quarterly of Human Rights, 324-357 available at <http://www.corteidh. or.cr/tablas/r26992.pdf> accessed 13 July 2015; MR Hutchinson, The Margin of Appreciation Doctrine in the European Court of Human Rights' (1999) 48 International and Comparative Law Quarterly, 638-650, as cited in M Hilf and TR Salomon, 'Margin of Appreciation Revisited: The Balance Pole of Multilevel Governance' in M Cremona and others (eds), Reflections on the Constitutionalisation of International Economic Law: Liber Amicorum for Ernst-Ulich Petersmann (Martinus Nijhoff Publishers 2014) 39.

36 ibid.

37 El Boudouhi (n 35) 1-2.

38 Hilf and Salomon (n 35) 40; El Boudouhi (n 35).

39 See eg Conseil d'Etat <http://www.senat.fr/rap/r11-705/r11-7054.html\#fnref11 $\geq$ accessed 1 September 2015; G Nolte, 'General Principles of German and European Administrative Law: A Comparison in Historical Perspective' (1994) 57 Modern Law 191.

40 Hilf and Salomon (n 35) 41.

41 Greece $v$ United Kingdom (n 5)

42 Van Dijk and Van Hoof, Theory and Practice of the European Convention on Human Rights (Kluwer 1998) 73-76. 


\subsection{Interpretive developments of the margin of appreciation under the European Convection on Human Rights}

The first two disputes, in which the ECtHR used the MoA - the 'Cyrpus' case $^{43}$ and Lawless $v$ Ireland ${ }^{44}$ - concerned a state of emergency. MoA was represented there as exoneration of the state from responsibilities under the Convention in exceptional situations in a time of public emergency, thus representing a delicate compromise between conflicting considerations of public interest.

In 1968, the ECtHR departed from situations of public emergency as typical of the application of MoA. Namely, in the Belgian Linguistics case, the Court introduced a wide scope for the emerging application of MoA. It established two key criteria for the interpretation of MoA: the proportionality principle, applied in a particular human rights context, and a focused consensus standard among member states of the Convention. ${ }^{45}$

Next followed the Handyside case that laid down the basics of most of the criteria for the interpretation and application of MoA, as well as special principles related to the concept: subsidiarity; the requirements of proportionality; the assessment of necessity in the context of the Convention; the Court's supervisory function; the principles characterising a democratic society; and the notion of pressing social need. ${ }^{46}$ I will track the main highlights of these developments below.

\subsubsection{Subsidiarity and the ECtHR's supervisory function}

As mentioned earlier, the ECHR is based on the idea that it is primarily the signatories of the Convention that are responsible for its respect and enforcement. The principle of subsidiarity is especially characteristic of the field of EU law, where it very generally means that domestic authorities should themselves decide democratically what is appropriate for their country (or, since the Lisbon Treaty, even for the region or municipality).$^{47}$ If talking about the idea of subsidiarity beyond the EU, in a broader perspective it is not necessarily about national authorities, but about making decisions at the 'lowest' or most local level.

The principle of subsidiarity within the ECHR regime states that the Strasbourg Court can by no means take the place of the national authorities, and may intervene only when the highest court of appeal in the

43 Greece $v$ United Kingdom (n 5)

44 Lawless $v$ Ireland App no 332/57 (ECHR 1 July 1961).

45 Belgian linguistic case (n 30) para 10.

46 Handyside (n 32) paras 48-49.

47 The Lisbon Treaty expressly mentions and reinforces this principle in Art 5(3) of the Treaty on European Union (TEU) and Protocol 2 on the application of the principles of subsidiarity and proportionality. 
concerned state has not ensured the application of the Convention, or has done so incompletely. ${ }^{48}$ The ECtHR supervisory function is a notion connected to subsidiarity, and generally says that the role of the Court is not that of the highest court of appeal of a country or of the 'fourth instance'. ${ }^{49}$

Particular emphasis was placed on the principle of effective protection as an essential part of the Convention. Namely, since the supervisory meaning of the Convention and the related function of the Strasbourg Court is the effective protection of human rights rather than the enforcement of mutual obligations between members of the Convention, the latter should not be interpreted restrictively in deference to sovereign legislative authority. ${ }^{50}$

\subsubsection{Discrimination and necessity}

As already mentioned, the proportionality principle was introduced by the ECtHR in the Belgian Linguistics case. Specifically, in that case, the Court defined discrimination as a difference between categories of person in the exercise of the Convention rights that has "no reasonable and objective justification'. ${ }^{51}$

Later, a distinction was established between 'different' treatment that is not discriminatory, meaning that interferences involving such treatment are permissible under the Convention, and discriminatory treatment properly speaking. In a series of decisions, the Court developed a wide scope for the emerging concept of MoA regarding, in particular, the reasonableness of a restriction placed by a member state on a right guaranteed by the Convention - and, four general factors have emerged as guidelines for establishing discrimination: ${ }^{52}$

(i) the treatment in question is less favourable than that received by other comparable groups, the identity of which will usually be determined objectively by the complaint itself; 53

(ii) the practice is unreasonable (reasons presented by the authorities are judged irrelevant and insufficient) and irrational (the means-end test shows that it is a disproportionate response to the need); 54

\footnotetext{
48 Handyside (n 32) para 48. See also Greer (n 13) 37; R Clayton and H Tomlinson, The Law of Human Rights (OUP 2000) 284-86.

49 Greer (n 13); Jagland, Human Rights Europe (n 20).

50 Greer (n 13) 15.

51 Belgian n 30) 1 dges, as well as urter Iback to me to see what we can shorten. way it was used by world trade judges, as well as urter I Linguistic case (n 30) para 10.

52 Based on Greer (n 13) 37.

53 Abdulaziz, Cabales, Balkandali $v$ the United Kingdom App no 9214/80; 9473/81; 9474/81 (ECHR 28 May 1985) para 74.

54 Abdulaziz (n 53) paras 74-84. See also Malone $v$ The United Kingdom App no 8691/79 (ECHR 2 August1984); Silver $v$ The United Kingdom App no 5947/72; 6205/73; 7052/75;
} 
(iii) the effects of the treatment are disproportionate in relation to the pursuit of the policy objective and fail to strike a balance between the protection of the interests of the community and respect for the rights and freedoms safeguarded by the Convention; ${ }^{55}$

(iv) the fourth factor actually determines the scope of the MoA: whether the practice in question is regarded as non-discriminatory in other democratic states. ${ }^{56}$

Note that, when assessing the necessity of different treatment as a distinction between categories in the exercise of Convention rights that is claimed to have reasonable and objective justification, the Court must evaluate whether or not such a 'pressing social need' exists. ${ }^{57}$ In this assessment, national authorities are allowed an MoA. It is in fact the evaluation of democratic necessity that lays down one of the already mentioned fundamental principles of interpretation, that is, the principle of proportionality. ${ }^{58}$ Namely, the proportionality test stricto sensu involves weighing and balancing between a pressing social need for some restriction of the Convention and a proportionate response to that need through such a restriction. This also involves assessing whether the reasons presented by the government are relevant and sufficient for this restriction to be non-discriminatory and necessary.

All in all, a treatment that is different for some categories in the exercise of Convention rights must be deemed discriminatory if it is proved unnecessary.

\subsubsection{A particular standard of 'European consensus'}

The last interpretative factors and principles of the previous section, namely, the 'pressing social need' factor, the subsequent principle of the evaluation of democratic necessity, as well as the englobing principle of whether the practice in question is regarded as non-discriminatory in other democratic states, together introduce a particular notion of 'European consensus' inside the ECHR regime. ${ }^{59}$

The ECtHR applies more often a teleological interpretation based on observed consensus rather than the intent of the drafters; the 'European

7061/75; 7107/75; 7113/75; 7136/75 (ECHR 23 March1983); Sunday Times $v$ The United Kingdom App no 6538/74, (ECHR 26 April 1979); Muller $v$ Switzerland App no 10737/84 (ECHR 24 May1988); and Vereinigung Demokratischer Soldaten Osterreichs und Gubi $v$ Austria App no 15153/89 (ECHR 19 December 1994).

55 Belgian Linguistic case (n 30) paras.34-35.

56 Marckx $v$ Belgium App no 6833/74 (ECHR 13 June 1979), para 41.

57 Handyside (n 32) paras 48-49.

58 RA Lawson and HGSchermers, Leading Cases of the European Court of Human Rights (ArsAequiLibri 1997) 29-40.

59 Marckx v Belgium (n 56) para 41; Handyside (n 32) paras 48-49. See also Greer (n 13) 11. 
Consensus' standard could thus be seen as a generic term used to describe the Court's enquiry into the existence or non-existence of a common ground, mostly in the law and practice of the contracting states. ${ }^{60}$

As the ECtHR ruled in the Handyside case, for instance, given that the legitimate objective was the protection of public morals, it did not manage to find a uniform conception of morals in the domestic law of the various member states because the requirements of morals varies from time to time and from place to place, especially in our era which is characterised by a rapid and far-reaching evolution of opinions on the subject'. ${ }^{61}$

Therefore, one may conclude that the non-existence of a European consensus on the subject-matter would imply a wider MoA accorded to the signatory state in question.

\section{The world trade regime in a nutshell}

Comprehensive historical and conceptual accounts of the GATT/ WTO regime have been chronicled elsewhere, and there is no need here to do more than concisely sketch some of its highlights. In this part, I outline the most general legislative as well as some key jurisprudential developments.

\subsection{The GATT/WTO basics}

The fundamental principles of the trading system as laid down by the GATT 1947 (now integrated into the GATT 1994 by reference), and taken over by the WTO at its creation in 1995, are the following:

(i) Gradual market liberalisation. Trade agreements do not end but must evolve over time. Continuing negotiations is a binding commitment made by a GATT member state at the moment of the signature of the GATT agreement.

(ii) Most-favoured-nation (MFN). Under the GATT/WTO agreements, members cannot in principle discriminate between their trading partners. If a member accords a special favour to 'like' imported goods from one country, it has to do the same for all WTO members. This principle is the first article of the GATT,

\footnotetext{
60 I de la Rasilla del Moral, 'The Increasingly Marginal Appreciation of the Margin of Appreciation Doctrine' (2006) 7(6) German Law Journal 617. See also R St J MacDonald, 'The Jurisprudence of the European Court of Human Rights' (1992) 1 (book 2) Collected Courses of the Academy of European Law, 95, 124, cited in Greer (n 13); Rudolf Bernhardt, 'Thoughts on the Interpretation of Human-Rights Treaties' in Franz Matscher and Herbert Petzold (eds), Protecting Human Rights: The European Dimension. Studies in Honour of Gérard J. Wiarda (Carl Heymans Verlag 1988) 65-67, 80-86.

61 Handyside (n 32) para 48.
} 
which governs trade in goods. MFN is also a priority under the General Agreement on Trade in Services (GATS) Article II, with some differences that are not relevant for my analysis, as the GATS is outside its scope. ${ }^{62}$

(iii) National treatment (NT). 'Like' imported and locally produced goods should be treated equally. NT only applies once a given trade object has entered the market. The principle of NT is found in all the main WTO agreements (eg GATT Article III, GATS Article XVII, SPS Article 2.3, TBT Article 2.1, etc), although the exact application of this principle slightly varies under each of the relevant agreements. ${ }^{63}$

Together, the MFN and NT principles and corresponding provisions in the GATT and other WTO agreements represent the non-discrimination norm of the GATT/WTO regime. The non-discrimination norm is so far the sole constraint on inward-oriented domestic measures under the original GATT. ${ }^{64}$ Notably, the concept of 'like products' within the GATT/ WTO regarding the non-discrimination provisions has a very particular meaning and particular criteria to determine each particular kind of measure. This is largely because the concept of 'likeness' was not defined in the GATT, but has been elaborated on a case-by-case basis. ${ }^{65}$ For example, the definition of criteria for products to be judged 'like' differs depending on whether the measure applying to the products in question is an internal taxation (GATT Article III:2) or an internal regulation (GATT Article III:4). GATT and other WTO provisions relevant for my analysis are those applying to domestic regulations. The elements of the widely used non-discrimination test are the following: a measure should be an internal regulation affecting 'like' products, and under this regulation imports should not be accorded 'less favourable treatment' than 'like' domestic products. In the famous EC-Asbestos case, the WTO Appellate Body, essentially drawing on the Border Tax Adjustments Report, ${ }^{66}$ reviewed

62 Guzman and Pauwelyn (n 3) 288-291.

63 WTO, 'Principles of the Trading System' < https://www.wto.org/english/thewto_e/whatis_e/ tif_e/fact2_e.htm > accessed 29 June 2015.

64 See eg A Porges and JP Trachtman, 'Robert Hudec and Domestic Regulation: The Resurrection of Aim and Effects" (2003) 37 Journal of World Trade 783, 783-84. See also T Cottier, 'Sovereign Equality and Graduation in International Economic Law' in M Cremona and others (eds), Reflections on the Constitutionalisation of International Economic Law. Liber Amicorum for Ernst-Ulrich Petersmann (Martinus Nijhoff Publishers 2014) 219.

65 For an excellent overview, see RE Hudec, "Like Product": The Differences in Meaning in GATT Articles I and III" in T Cottier and P Mavroidis (eds), Regulatory Barriers and the Principle of Non-Discrimination in World Trade Law (University of Michigan Press 2000) 107-15. See also Cottier (n 64).

66 GATT Working Party Report, Border Tax Adjustments, 2 December 1970, GATT BISD (18th Supp) $97 \mathrm{ff}$. 
and established the four factors of likeness based on the market logic as follows: physical characteristics, end use, consumer tastes and habits, and tariff classification. ${ }^{67}$ The EC-Asbestos case will be explored in detail in the relevant sections that follow.

\subsection{Article XX of the GATT: departure from free trade obligations}

Here, the approaches used by world trade adjudicators can be very roughly divided into 'before' and 'after' the creation of the WTO.

\subsubsection{The main and relevant interpretative lines under GATT Article XX}

Under the GATT, even if a measure of a member is deemed to violate the above principles, it might still be consistent with the GATT if that measure falls under one of the exceptions of GATT Article XX. Again, complete explanations of the fundamentals of GATT Article XX have been extensively narrated elsewhere, ${ }^{68}$ and there is no need for me to do more than briefly outline the main highlights that may directly relate to domestic regulations with societal objectives. Therefore, the analysis that follows concerns the two provisions of Article XX, which are the most relevant for my analysis: exceptions that concern human, animal and plant life and health (Article XX (b)) and environmental measures (Article XX (g)).

The analysis of the consistency of a measure under GATT Article XX is two-tiered. ${ }^{69}$ First, the subsections of Article XX relevant for domestic measures that I will address under the TBT could allow otherwise inconsistent trade restrictions if they are 'necessary' to protect human, animal, or plant life or health $(\mathrm{XX}(\mathrm{b}))$ or if they are 'relating to' the conservation of exhaustible natural resources (XX(g)). Second, even if Article XX conditions are met in accordance with one of mentioned paragraphs, the measure must yet fulfil the requirements of the Article XX introductory clause (the so-called chapeau). That is, it should be established that such

\footnotetext{
$67 \quad$ EC-Asbestos (n 11) para101.

68 To quote just a few, see eg S Charnovitz, 'Exploring the Environmental Exceptions in GATT Article XX' (1991) 25 Journal of World Trade 37-55; H Horn and P Mavroidis, 'ECAsbestos' in H Horn and P Mavroidis (eds), The American Law Institute Reporters' Studies: The WTO Case Law (CUP 2007-2008) 27-53; M McRae, 'GATT Article XX and the WTO Appellate Body' in M Bronckers and R Quick (eds), New Directions in International Economic Law: Essays in Honour of John H Jackson (Kluwer Law International 2000); L Ehring, "The EU Approach to Article XX GATT Case-Law', paper presented at the SIEL 2014 Bern Global Conference, 10 July 2014, World Trade Institute, University of Bern.

69 For comprehensive accounts of the Article XX GATT application, see eg J Jackson, W Davey and A Sykes, Legal Problems of International Economic Relations: Cases, Materials and Text on the National and International Regulation of Transnational Economic Relations $\left(6^{\text {th }}\right.$ edn, Thomson/West 2013) 591-610; Guzman and Pauwelyn (n 3) 339-404; Mavroidis et al (n 1) 684-724. For its application on environment-related measures, see eg International Centre for Trade and Sustainable Development (ICTSD), 'Competitiveness and Climate Policies: Is There a Case for Restrictive Unilateral Trade Measures?' (2009) ICTSD Programme on Competitiveness and Sustainable Development, Information Note No 16.
} 
a restriction is not a means of 'arbitrary or unjustifiable discrimination' or a 'disguised restriction on trade', as specified in the chapeau.

Regarding GATT Article XX(b), in order to appreciate whether possible violations of the above GATT obligations would be justified by the exception under this provision, a panel will have to analyse: (i) whether the policy falls within the range of measures designed to protect human, animal or plant life or health; (ii) and the meaning of 'necessary', therefore verifying whether the policy fulfils the criteria for being 'necessary' as laid down by the GATT and interpreted and applied by the WTO DSB.

As for the notion of necessity under XX(b), in sum, the word 'necessary' is not limited to the term absolute necessity. Determination of whether a measure (which is not indispensable) is 'necessary' involves weighing such factors as: (i) the contribution of the measure to the ends pursued (the 'means-end' test) $;{ }^{70}$ (ii) the importance of the common interests or values protected; ${ }^{71}$ and (iii) the overall impact of the measure (the 'effects' test). In respect of the appreciation of necessity, it is interesting to note that it may be used by WTO panels as a particularly convenient and important juridical instrument when dealing with domestic regulation, as it allows them to differentiate between regulations that have an inadvertent and inevitable negative impact on trade, and regulations that have an unintended but avoidable trade-distorting impact. ${ }^{72}$ While the latter is not justifiable under $\mathrm{XX}(\mathrm{b})$, the former might be justifiable because it is 'necessary', as it is otherwise simply inevitable.

A general opinion exists that countries seeking to justify various socially imperative policies related to human health, but doing so indirectly, would rather resort to Article XX(g) than (b). ${ }^{73}$ One of the reasons, it is claimed, is that the requirement 'necessary' in Article XX (b) is generally perceived as more strict, and thus more difficult to meet than the requirement of 'relating to' in Article XX(g); furthermore, following this logic, commentators often prefer to defend measures that can fall under both of these provisions under Article XX(g). ${ }^{74}$ The lines that follow briefly consider the common trends of WTO case law relevant for Article XX(g) GATT.

According to the US-Gasoline ruling, this 'relating to' test requires that there must be a substantial relationship between the regulation and

\footnotetext{
70 United States-Import Prohibition of Certain Shrimp and Shrimp Products [US-Shrimp]: Report of the Appellate Body (12 October 1998) DS58, para141; Brazil-Tyres (n 11) para 93.

${ }^{71}$ EC-Asbestos (n 11) para 115.

72 A Lang, World Trade Law After Neoliberalism (CUP 2011) 265.

73 See Guzman and Pauwelyn (n 3) 339-404. See also L Bartels, The Inclusion of Aviation in the EU ETS: WTO Law Considerations' (2012) 6 ICTSD Trade and Sustainable Energy Series (April 2012) 15.

74 Guzman and Pauwelyn (n 3). .
} 
the public interest objective, ${ }^{75}$ eg an environmental regulation and the conservation of the planet's atmosphere. In like manner, as held in USShrimp, it is required that the 'means [should be] related to the ends', ${ }^{76}$ ie that the measure must be expressly designed to contribute to attaining an environmental goal. In addition, there should be a sufficient jurisdictional nexus for the measure. ${ }^{77}$ Finally, the regulation must be taken in conjunction with the restrictions on relevant domestic production or consumption. ${ }^{78}$

In this respect, consider the example of the atmosphere. In US-Gasoline, both the panel and the $\mathrm{AB}$ determined that clean air was an exhaustible natural resource within the meaning of Article XX(g) GATT. ${ }^{79}$ Although the atmosphere and clean air are not synonymous, it would however seem consistent to consider the atmosphere as an exhaustible natural resource, too. ${ }^{80}$ With regard to the close relationship between the means and the ends, as well as a jurisdictional nexus, the atmosphere, just like the air, is everywhere. ${ }^{81}$ So, in this example, countless inwardoriented domestic measures with an inadvertent extra-territorial effect somehow related to the fight against climate change and for the conservation of the atmosphere are likely to be justifiable under Article XX.

The next step is an assessment of the measure's conformity with the requirements of the chapeau. The measures under any of the paragraphs of GATT Article XX should be examined against the background of the general chapeau's criteria, which were introduced in the AB's first ever decision, and were confirmed in subsequent rulings: (i) 'arbitrary discrimination' (between countries where the same conditions prevail); (ii) 'unjustifiable discrimination' (with the same qualifier); and (iii) 'disguised

\footnotetext{
75 United States-Standards for Reformulated and Conventional Gas [US-Gasoline]: Report of the Panel (29 January 1996) DS2, para 6.37. See also United States-Standards for Reformulated and Conventional Gas [US-Gasoline]: Report of the Appellate Body (20 May 1996) DS58. Unlike current AB reports, this early report does not feature numbered paragraphs.

76 US-Shrimp (n 70) para141.

77 ibid, paras 133 and 137.

78 US-Gasoline (n 75); US-Shrimp (n 70) paras 133-45.

79 See eg US-Gasoline (n 75) para 6.36.

80 See eg J Meltzer, 'Climate Change and Trade: The EU Aviation Directive and the WTO' (2012) 15 Journal of International Economic Law 111, 141-142; W Maruyama, 'Climate Change and the WTO: Cap and Trade Versus Carbon Tax' (2011) 45 Journal of World Trade, 679, 695; J Pauwelyn, 'US Federal Climate Policy and Competitiveness Concerns: The Limits and Options of International Trade Law' (2007) 38 ICTSD Programme on Trade and Environment, 35; R Howse and A Eliason, 'Domestic and International Strategies to Address Climate Change: An Overview of the WTO Legal Issues' in T Cottier, O Nartova and $\mathrm{S}$ Bigdeli (eds), International Trade Regulation and the Mitigation of Climate Change (CUP 2009) 61.

81 See also R Howse commenting on L Bartels: namely, Howse keenly pointed out that 'climate change is a global problem with effects everywhere'. In Bartels (n 73) 29.
} 
restriction' on international trade. ${ }^{82}$ To these general conditions an assessment of the design of the measure itself, as well as its application (ie whether it is just restrictive or discriminatory) should be added, ${ }^{83}$ and also whether the external reasons may explain this differential treatment. ${ }^{84}$

As to the chapeau test for environmental and health measures, in previous disputes the $\mathrm{AB}$ has already elaborated on the content of such criteria. ${ }^{85}$ The most relevant for the environmental and health measures criteria include the following:

(i) Does the measure take into account the local conditions in foreign countries or does it essentially require foreign countries to adopt their own policies?

(ii) Before imposing unilateral environmental measures, did the country in question engage in serious, across-the-board negotiations with the objective of concluding bilateral or multilateral agreements to address climate change? (It may be that the chapeau demands the concerned state to undertake efforts to negotiate an international agreement as a precondition to the fallback of unilateral measures. ${ }^{86}$ However, according to US-Shrimp, this does not require the actual conclusion of an agreement. ${ }^{87}$

(iii) Does the implementation and administration of the measure respect basic fairness and due process? More specifically, any discrimination in the application of the conflicting measure should 'relate to the pursuit of the measure'. ${ }^{88}$

\subsubsection{Relevant GATT jurisprudence}

For the most part, unilateral measures that might somehow restrict trade, even if advancing societal causes, have initially hardly been tolerated by the enforcement of the rules and norms of the world trade regime.

The most relevant rulings issued under the 'old regime', namely before the creation of the WTO in 1995, are US-Tuna (Canada), Canada-Her-

\footnotetext{
82 US-Gasoline (n 75) 23. See also relevant reasoning in US-Shrimp (n 70), EC-Asbestos (n 11) and Brazil-Tyres (n 11).

83 Brazil-Tyres (n 11) para 246.

84 ibid. See eg paras145-6, 150-1, 154, 232-3 and 247. See also European Communities - Measures Prohibiting the Importation and Marketing of Seal Products [EC-Seals]: Report of the Appellate Body (22 May 2014) DS400 paras 5.208-215.

85 For a comprehensive overview of the chapeau principles and the criteria to meet for there to be a justified exception, in particular regarding 'good faith', see O Perez, Ecological Sensitivity and Global Legal Pluralism: Rethinking the Trade and Environment Conflict (Hart Publishing 2004) 82-83; Guzman and Pauwelyn (n 3) 391.

86 US-Gasoline (n 75) paras 27-28.

87 US-Shrimp (n 70) paras 122-123.

88 Brazil-Tyres (n 11) para 93.
} 
ring, Canada-Ice Cream, Thailand-Cigarettes, US-Taxes on Automobiles, and two Tuna-Dolphin disputes - mainly because they all looked at GATT Article XX public policy exceptions.

In the seven cases, GATT panels had to interpret the exceptions invoked as a justification of a party's otherwise discriminatory measures related to national social imperatives. And in all cases, the panels performed quite a narrow analysis of GATT exceptions. ${ }^{89}$

In particular, in the Canada-Ice Cream case, a GATT panel set the benchmark at which GATT public policy exceptions were to be interpreted - ie narrowly:

a contracting party invoking an exception to the General Agreement [not only] bore the burden of proving that it had met all of the conditions of that exception [...], [but also] that exceptions were to be interpreted narrowly. ${ }^{90}$

In 1990, in the Thailand-Cigarettes case, Thailand argued that its import restrictions on US cigarette imports were justified under GATT Article XX(b) because the government had adopted measures that could only be effective if cigarette imports were prohibited and because chemicals and other additives contained in US cigarettes might make them more harmful than Thai cigarettes. ${ }^{91}$ Notably, the panel stated 'that GATT $\mathrm{XX}(\mathrm{b})$ clearly allowed contracting parties to give priority to human health over trade liberalisation; however, for a measure to be covered by Article $\mathrm{XX}(\mathrm{b})$ it had to be "necessary" (emphasis added). ${ }^{92}$ The panel eventually ruled that Thailand's import restrictions were not 'necessary' within the meaning of Article XX(b).

The most notable of the pre-WTO disputes was the Tuna row. The first Tuna case was brought to the GATT in 1991. Mexico challenged the US Marine Mammal Protection Act (MMPA) prohibiting the 'taking' ('harassment, hunting, capture, killing or attempt to do any of these'), and importation into the US of marine mammals, in particular the taking of marine mammals incidental to harvesting yellowfin tuna in the Eastern

\footnotetext{
89 United States - Prohibition of Imports of Tuna and Tuna Products from Canada: Report of the Panel (22 February 1982) L/5198-29S/91, 108; Canada-Measures Affecting Exports of Unprocessed Herring and Salmon: Report of the Panel (22 March 1988) L/6268-35S/98, 113; Canada - Import Restrictions on Ice Cream and Yoghurt (BISD 36S/68), adopted at the Forty-fifth Session of the contracting parties (5 December 1989) L/6568 - 36S/68, see eg paras 8-17, 30-31; United States - Taxes on Automobiles: Report of the Panel DS31/R, unadopted, circulated on 11 October 1994, see eg paras 5.56-5.57, 5.59-5.66.

90 Canada-Ice Cream (n 89) para 59.

91 Thailand - Restrictions on Importation of and Internal Taxes on Cigarettes: Report of the Panel (7 November 1990) DS10/R-37S/200.

92 Thailand-Cigarettes (n 91) para 73.
} 
Tropical Pacific Ocean, an area where dolphins are known to swim above schools of tuna. The act meant embargoes on the imports of tuna that had been caught with commercial fishing technology resulting in the incidental kill or incidental serious injury of ocean mammals in excess of US standards. ${ }^{93}$ The second Tuna dispute was initiated by the Netherlands and the EC complaining that both the primary and the intermediary nation embargoes, enforced pursuant to the MMPA, violated GATT Article XI: 1 and were not covered by any of the exceptions of Article XX. ${ }^{94}$

In both Tuna-Dolphin cases, the question relevant to this section for response by the GATT panels was whether the two otherwise 'like' products were actually not 'like' because of the difference in their process and production method (PPM). ${ }^{95}$ The essential rationale of the PPM issue vis-à-vis the trade law is whether the 'like' products with a different PPM could be treated differently by the parties to the world trade regime. The relevant - though not exclusive - idea behind the PPM conception relating to GATT Article XX refers to the processes that may somehow have harmful side effects: eg, they may affect the environment, the health and life of human and other living beings, human security, morals, etc, during the production of a good, while the final product may be perfectly similar to other products of that group. In the Tuna-Dolphin disputes, it was the way in which the conflicting US regulations required the fishing of tuna to be carried out. ${ }^{96}$ The answer that both Tuna panels found to the above question regarding different PPMs for otherwise 'like' products was 'no': no, under GATT rules on national treatment and quantitative restrictions, the US could not treat the same tuna in a different manner because of differences in its harvesting. ${ }^{97}$

As regards GATT exceptions, the panels proceeded as follows. In $\mathrm{Tu}$ na-Dolphin I, the US argued that the measure in question intending to promote foreign environmental conservation was covered by GATT Articles XX(b) and (g). The GATT panel expressed fear that any justification under Article XX might lead to 'green protectionism'. ${ }^{98}$ So the panel considerably reduced the scope of application of the provisions by excluding

93 Based on WTO, 'Environment < https://www.wto.org/english/Tratop_e/envir_e/ edis04_e.htm > accessed 31 May 2014.

94 ibid.

95 United States - Restrictions on Imports of Tuna [Tuna-Dolphin 1]: Report of the Panel, unadopted, circulated on 3 September 1991, eg paras 5.7-5.10; United States - Restrictions on Imports of Tuna [Tuna-Dolphin II]: Report of the Panel, unadopted, circulated on 19 June 1994, eg paras 5.7-5.9.

96 Tuna-Dolphin I (n 95) paras 5.9-5.15; Tuna-Dolphin II (n 95) para 5.9.

97 Tuna-Dolphin I (n 95) paras 5.15-16 and 5.18; Tuna-Dolphin II (n 95) paras 5.8-5.10.

98 See D C Esty, Greening the GATT: Trade, Environment, and the Future (Institute for International Economics 1994) as cited in A Peters and others The Constitutionalisation of International Trade Law' in T Cottier and P Delimatsis (eds), The Prospects of International Trade Regulation. From Fragmentation to Coherence (CUP 2011) 85. 
practically all unilateral trade measures. ${ }^{99}$ This was mostly because they were unilateral measures and trade measures, rather than because they were socially imperative ones. The destiny of the US claims for justifications under GATT Articles XX(b) and (g) in Tuna - Dolphin II was the same - all less restrictive options had first to be pursued before imposing such a trade restrictive measure. ${ }^{100}$ As regards necessity (the criterion to be applied under GATT XX(b)) and primary aim (the relevant criterion of GATT $\mathrm{XX}(\mathrm{g})$ ) of the US regulation, in both disputes the panels decided that the conflicting measures could not be deemed as either 'primarily aimed' at the conservation of dolphins, or 'necessary' for the protection of their life. It is important to stress here that, basically until the EC-Asbestos dispute, the standard of review under GATT Article XX adopted by world trade tribunals was symmetrical across various provisions of the article. ${ }^{101}$ Namely, the adjudicators were paying attention to the means used to meet a certain societal objective rather than examining the legitimacy of the ends of such an objective. ${ }^{102}$ Hence there were parallel standards of review, eg under both 'necessary' and 'primarily aimed', in earlier GATT/ WTO cases. As mentioned, the situation changed after the AB ruling in EC-Asbestos, where it held that the legitimacy of each particular objective in question should be assessed (in this case, under the 'necessary' standard of review only). ${ }^{103}$

It is interesting to note that neither of the two Tuna panels examined the legality of the conflicting regulation with regard to world trade law through the application of the chapeau of GATT Article XX. Moreover, none of the panels settling the other three relevant GATT disputes dealing with the environmental issues under GATT Article XX(g) (US-Tuna (Canada), Canada-Herring, US-Taxes on Automobiles), and the one applying Article XX on health measures (Thailand-Cigarettes), completed the analysis by continuing with the chapeau application in the cases at hand.

Notably, the two (though unadopted - hence without the status of a legal interpretation of GATT law) Tuna panel reports marked the beginning of a new era of adjudication in the global trade regime, namely that of the 'trade and...' debate. Around 1995, following the relevant rulings, the 'trade' side outweighed the 'and...' side, as the public interest objectives of one member clearly could not prevail over the free trade objectives of the trading community as a whole. The GATT legal standards of non-

\footnotetext{
$99 \quad$ Tuna-Dolphin I (n 95) paras 5.8-5.14; 5.27.

100 Tuna-Dolphin II (n 95) paras 5.8-5.9.

101 See eg US-Taxes on Automobiles (n 89) paras 5.56-5.57; 5.59-5.66; Korea- Measures Affecting Imports of Fresh, Chilled and Frozen Beef [Korea-Beef]: Report of the Appellate Body (11 December 2000) DS161, para 176.

102 Mavroidis et al (n 1) 691.

103 EC-Asbestos (n 11) 172.
} 
discrimination were not balanced against competing non-trade standards and interests - rather, a clear hierarchy of structural values of the GATT was underlined: the non-discrimination rules first, and the public policy exceptions after. ${ }^{104}$

\subsubsection{Relevant WTO jurisprudence}

Right after the inception of the WTO, the three decisions on the cases that followed considerably changed the direction of the 'trade and...' debate. So, in order to demonstrate quite a sharp contrast in the interpretation of world trade law applying to domestic societal regulation, I will concentrate on the first three relevant rulings by the WTO DSB, though occasionally referring to different later disputes where relevant. My general aim here is not to discuss at length the totality of WTO jurisprudence under GATT Article XX, but to track the main highlights of WTO rulings deciding on domestic societal regulation under the GATT that might be relevant for my analysis of TBT case law. Indeed, law and its application do not remain static but naturally evolve over time - not only within the GATT/WTO, but basically in any legal regime. Therefore, my methodological option is rather to address earlier relevant decisions under the WTO. The main reason for such a selection is that, otherwise, the interpretive choices and attitudes in cases with twenty to thirty years between them are unsurprisingly very different anyway. That is, more recent decisions would be more up-to-date and would better correspond to their actuality and related current events, whatever the latter are. Discussing judicial decisions with only a few years between them, as I do here, but still with quite different interpretative politics, seems to me to be more illustrative.

The first is the US-Gasoline case. In January 1995, Venezuela complained to the newly created WTO DSB that the US was applying rules that discriminated against Venezuelan gasoline imports. The case arose because of the Gasoline Rule under the US Clean Air Act that set out the rules for establishing baseline figures (an average standard) for gasoline sold on the US market. The Gasoline Rule was applicable to refiners, blenders and importers of the product, and required that certain chemical characteristics of the gasoline in which they dealt respect, on an annual average basis, defined levels. Some of these levels were fixed, and others were expressed as 'non-degradation' requirements. ${ }^{105}$ This translated into stricter requirements for the chemical characteristics of imported gasoline than for domestically-refined gasoline. The stated purpose of this provision was to regulate the composition and emission effects of

\footnotetext{
${ }^{104}$ In this sense, see similar conclusions in Perez (n 85) 54. See also Guzman and Pauwelyn (n 3) 283.

${ }^{105}$ US-Gasoline (n 75) para 6.2ff.
} 
gasoline so as to prevent air pollution. ${ }^{106}$ Venezuela (and later Brazil) said it violated the NT principle and could not be justified under exceptions to the GATT rules for health and environmental conservation measures. ${ }^{107}$

Established for the first time under the WTO, the panel found that the measure treated imported gasoline less favourably than domestically refined gasoline. It thus violated the NT provision. In particular, under the measure at issue, the statutory baseline had no connection to the particular gasoline imported, while refiners of domestic gasoline had only to meet a standard linked to their own product in 1990, a different, individual refinery baseline. ${ }^{108}$ Regarding the exceptions, the panel considered the case under three provisions of GATT Article XX (as per US submissions): (b), (d), and (g). ${ }^{109}$ Given that the most relevant one was GATT $\mathrm{XX}(\mathrm{g})$, the panel examined in detail whether clean air was an exhaustive natural resource. ${ }^{110}$ It concluded that it was, but that, overall, the US measure did not benefit from the Article XX exception - either under paragraph $(\mathrm{g})$, or the other two. ${ }^{111}$

Regarding the application of general exceptions, the AB adjusted the panel's interpretation. Namely, it held regarding the exception at hand - the conservation of exhaustible natural resources under GATT Article $\mathrm{XX}(\mathrm{g})$ - that, instead of relying on the relevant reasoning of earlier (GATT) panels, the panel should have interpreted 'measures' more broadly under Article XX to include provisions not themselves found inconsistent with Article III:4. ${ }^{112}$ The AB further detailed that the 'measure', ie the baseline establishment rules, and not the 'less favourable treatment' (as the panel held), was "primarily aimed at" (related to) the conservation of exhaustible natural resources, but still concluding that Article XX(g) was not applicable in this case. ${ }^{113}$ As I have already mentioned above, the 'relating to' test requires that there be a substantive relationship between the conflicting measure and the public interest objective, ie an environmental regulation should clearly relate to the conservation of an exhaust-

\footnotetext{
106 As already mentioned, unlike current AB reports, this very first report does not feature numbered paragraphs. Therefore, see directly US-Gasoline (n 75). See also WTO, 'WTO Dispute Settlement: One-Page Case Summaries' (2012) $7<$ http://www.wto.org/english/ tratop_e/dispu_e/cases_e/ds2_e.htm > accessed 31 May 2014.

107 ibid.

108 US-Gasoline, paras 6.5-6.17.

109 ibid, para 6.20ff.

110 ibid, para 6.37.

111 ibid, paras 6.37 and 6.41 .

${ }^{112}$ It held that there was no need at all to examine whether the whole of the Gasoline Rule or any of its other rules was saved or justified by Article XX(g). The Panel here was following the practice of earlier panels in applying Article XX to provisions found to be inconsistent with Article III:4: the "measures" to be analyzed under Article XX are the same provisions infringing Article III:4'. US-Gasoline (n 75) 13-14.

113 ibid, $14 \mathrm{ff}$.
} 
ible natural resource. Notably, in this case, both the panel and the AB determined that clean air was an exhaustible natural resource within the meaning of GATT Article XX(g).

In its very first decision, the $\mathrm{AB}$ introduced a number of other landmark concepts and interpretive principles that were used and complemented in subsequent disputes. One of them is the concept of 'calibrated measures': the regulation must be taken in conjunction with the restrictions on relevant domestic production or consumption. A connected concept is the requirement of 'even-handedness' in the imposition of restrictions, even if in the name of the conservation of exhaustible natural resources, upon the production or consumption of exhaustible natural resources. ${ }^{114}$ Another one is the empirical 'effects test': the AB noted that

in the first place, the problem of determining causation, wellknown in both domestic and international law, is always a difficult one. In the second place, in the field of conservation of exhaustible natural resources, a substantial period of time, perhaps years, may have to elapse before the effects attributable to implementation of a given measure may be observable. ${ }^{115}$

The AB also noted that, under the chapeau of GATT Article XX, 'good faith' in the GATT/WTO context implied that a conflicting measure was not a means of 'arbitrary or unjustifiable discrimination' or a 'disguised restriction to trade'. (Generally, in law, and in particular in traditional international law, the concept of good faith (or bona fide) is one of the principles underlying the legal doctrine of 'abus de droit': together with the two other principles, ie fairness and justice, it aims at preventing the actual abusive exercise by a legal subject of its own legal right - that is, when a right is formally exercised in conformity with the conditions laid down in the rule granting the right, but where the legal outcome is against the objective of that rule, the objective of that rule thus not being achieved. ${ }^{116}$ )

Eventually, regarding the legality of the disputed US measure vis-àvis the chapeau, the $\mathrm{AB}$ concluded that a failure to negotiate in good faith and seek the cooperation of foreign states amounted to unjustifiable discrimination and disguised restriction on international trade and hence failed to satisfy the chapeau's criteria of good faith. ${ }^{117}$

\footnotetext{
114 ibid, 21.

115 ibid.

${ }^{116}$ For civil law, see D Johnston, Roman Law in Context (CUP 1999) 71-76. For common law, see eg JG Fleming, The Law of Torts (8th edn, The Law Book Company 1992) 623. For public international law, see eg A Kiss, 'Abuse of Rights' in R Bernhardt (ed), Encyclopedia of Public International Law (vol 1, North-Holland 1992) 4.

117 US-Gasoline (n 75) 22ff.
} 
The second relevant incident happened in early 1997 when India, Malaysia, Pakistan and Thailand brought a joint complaint against a ban imposed by the US on the importation of certain shrimp and shrimp products. A ban was imposed on shrimp caught without a 'turtle excluding device' (TED) - this applied initially to catch from the western hemisphere and, subsequently, worldwide. The protection of sea turtles was at the heart of the ban. The US Endangered Species Act of 1973 listed as endangered or threatened the five species of sea turtles that occur in US waters, and prohibited their 'take' within the US, in its territorial sea and the high seas. ${ }^{118}$ In 1998, when deciding the US-Shrimp case, the AB acknowledged that the referred state public policy exception could be excused under relevant paragraphs of GATT Article XX as this concerned an exhaustible natural resource, but eventually could not be considered justified or non-arbitrary under the chapeau. ${ }^{119}$

By insisting that identical conservation schemes be adopted abroad, the US unilateral implementation of uniform trade measures was characterised as clearly prescribing compliance with, or adoption of, certain polices to other WTO members, and though not prohibited by the GATT, this simply could not be tolerated by the world trading regime. ${ }^{120}$ Nevertheless, US-Shrimp became a landmark case where the WTO AB rejected the narrow interpretation of the exceptions applied to the socially imperative regulations of the state, laid down by the GATT panels in the two Tuna cases. Namely, measures falling under the scope of the subsections of GATT Article XX were 'recognised as exceptions to substantive obligations' under the GATT/WTO system as the corresponding policies 'have been recognised as important and legitimate in character'. ${ }^{121}$ However, such measures would still need to be established as non-protectionist, that is, to pass the test of the chapeau of Article XX.

In order not to miss the full importance of the AB's ruling in this case, it is important to emphasise several points. First, in its report, the $\mathrm{AB}$ made clear that under WTO rules, countries have the right to take trade action to protect the environment (in particular, human, animal or plant life and health) and endangered species and exhaustible resources. ${ }^{122}$ The WTO does not have to 'allow' them this right, as it does not have such wide discretion. ${ }^{123}$ It also said that measures to protect sea turtles would be legitimate under GATT Article XX that deals with vari-

\footnotetext{
${ }_{118}$ Based on WTO, summary of the US-Shrimp case < http:/ / www.wto.org/english/tratop_e/ dispu_e/cases_e/ds58_e.htm> accessed 31 May 2015.

119 US-Shrimp (n 70) paras 161-163.

120 ibid, para 121.

121 ibid, para 121.

122 ibid, paras 133 and 161.

123 ibid, para 161.
} 
ous exceptions to the WTO's trade rules, provided certain criteria such as non-discrimination were met. ${ }^{124}$

Thirdly, the panel working on this case before the appeal actually tried to bring back the narrow vision of GATT exceptions. It attempted to do so through something that the two GATT Tuna panels omitted to do ie by applying the chapeau. Nevertheless, the message of the US-Shrimp panel was the same as that of the GATT era panels: members' domestic measures of a 'lower' - eg environmental - order that compete with the world trade rules, and which therefore affect the multilateral trading regime as a whole, should not even be considered under GATT Article XX (this time, its chapeau). ${ }^{125}$ The AB reversed this application of Article XX by the panel. It stated that, generally, the goal of the overall safety of the multilateral trading regime is not the rationale of the chapeau of GATT Article XX, nor is it an interpretative rule, right or obligation under the chapeau. ${ }^{126}$ Conversely, the chapeau's aim is to ensure that GATT exceptions are invoked in good faith, hence serving the goal of avoiding the manipulation of Article XX. ${ }^{127}$

The next point is that the $\mathrm{AB}$ ruled that the chapeau was a manifestation of the 'principle of good faith', referring to the US-Gasoline decision where it had already explained that the 'good faith' in the GATT/WTO context meant that a conflicting national regulation was not a means of 'arbitrary or unjustifiable discrimination' or a 'disguised restriction to trade'. ${ }^{128}$ The AB equally stated that the assessment of the good faith of the government implementing the conflicting measure could be not only an a priori analysis, ie of the design of the measure, but also an a posteriori review, ie of its actual implementation. ${ }^{129}$

It is particularly important to note that in deciding whether the US regulation passed the chapeau test, the $A B$ invoked an inquiry of the way the measure was substantively applicable in practice (ie as opposed to the form in which it was designed and administered) as another potential criterion for scrutiny. That is, as I mentioned earlier, regarding the "meansend' relationship, the $\mathrm{AB}$ held in US-Shrimp that the measure must be expressly put in place to 'effectively contribute' (actual implementation) to attaining an environmental goal. ${ }^{130}$ In addition, there should be a sufficient

\footnotetext{
${ }^{124}$ Based on WTO, 'Environment: Disputes' <http://www.wto.org/english/tratop_e/ envir_e/edis08_e.htm> accessed 2 June 2015.

125 US-Shrimp (n 70). See eg paras 7.43-45, 7.49-50.

126 US-Shrimp (n 70) para 116.

127 ibid, paras 151 and 158.

128 ibid.

129 ibid, para 160.

130 ibid, para 141.
} 
jurisdictional nexus for the measure. ${ }^{131}$ So, the substantive application of the measure in practice was opposed to the form in which it was designed on paper, as the $\mathrm{AB}$ mentioned in this case in the chapeau analysis. This point is very interesting for my later analysis of TBT relevant jurisprudence. I will therefore come back to it further in the article.

At this point, it is important to stress that the actual implementation of measures should be clearly distinguished from the actual effects of the measures (the latter is the empirical 'effects test'). That is, as has already been noted in US-Gasoline, the effects attributable to implementation should be distinguished from the implementation itself. More precisely, regarding the environmental conservation measures, the $A B$ stated in that case that a considerable period of time, perhaps many years, should pass before any actual effects of an environmental regulation might be observable. So, this should be borne in mind when reading the US-Shrimp judgment, particularly the AB's observations on the actual implementation of domestic measures.

Finally, and importantly, the $\mathrm{AB}$ held that the chapeau is there to take care of both sides of the 'trade and...' debate and to balance between the competing norms of two different natures, thus implying that the legal norms of GATT exceptions are equal to the legal norms of GATT rules. ${ }^{132}$

Later, in US-Shrimp Article 21.5, the AB admitted that unilateralism alone would not disqualify the measure under GATT Article XX (something which was not entirely clear after the AB report in the initial US-Shrimp dispute). ${ }^{133}$ In this case, in order to implement the recommendations and rulings of the AB, the US issued Revised Guidelines for the Implementation of Section 609 of Public Law 101-162 Relating to the Protection of Sea Turtles in Shrimp Trawl Fishing Operations. These Guidelines replaced the ones issued in April 1996 that were part of the original measure in dispute. The Revised Guidelines set forth new criteria for the certification of shrimp exporters. In 1997, Malaysia introduced an action pursuant to Article 21.5 DSU, arguing that the US had not properly implemented the findings of the $\mathrm{AB}$ in the dispute. However, the compliance panel held that US implementation of the ruling was justified under GATT Article XX as long as the conditions stated in the findings of the Report, in particular the on-going serious good faith efforts to reach a multilateral agreement, remained satisfied. The AB thus upheld the contested findings of the compliance panel. ${ }^{134}$

\footnotetext{
131 ibid, paras 133 and 137.

132 ibid, paras 156-159.

133 US-Shrimp, Recourse to Article 21.5 of the DSU by Malaysia [US-Shrimp Article 21.5]: Report of the Appellate Body (22 October 2001) DS58, para138. See also D Schneiderman, Constitutionalizing Economic Globalization: Investment Rules and Democracy's Promise (CUP 2008) 66.

${ }^{134}$ WTO summary (n 118).
} 
In the second US-Shrimp report, the AB clarified what it had already introduced in US-Gasoline and the first US-Shrimp decisions: the chapeau's aim is to prevent manipulations of GATT Article XX with the help of the good faith principle. ${ }^{135}$ As I have already mentioned in the above introduction of the general analysis of Article XX, this would include: (i) an inquiry into whether the measure takes into account the local conditions in other countries or if it essentially requires that foreign countries have to adopt their own policies; (ii) a requirement to explore whether the respondent country has engaged in serious, across-the-board negotiations with the objective of concluding bilateral or multilateral agreements to address the socially imperative issue in question (however, according to the first US-Shrimp decision, this does not require the actual conclusion of an agreement); and (iii) a condition that the implementation and administration of the measure respect basic fairness and due process. Hence, the AB laid down the fundamental criteria for the application of the good faith principle for the purposes of the non-discrimination analysis of the interpretation of GATT exceptions. Let me just make a remark to recall that earlier in this analysis it was mentioned that the normative framework of the TBT per se seeks to discipline the domestic process of the implementation and administration of technical regulations. Therefore, it would also be worth examining whether the above good faith requirements or comparable criteria were applied by the $\mathrm{AB}$ in the recent settlement of TBT disputes.

This case, as some commentators have argued, could have been decided under the TBT. ${ }^{136}$ In May 1998, Canada filed a complaint to the WTO concerning France's 1996 Decree on the prohibition of the importation and sale of asbestos and asbestos-containing products. Canada claimed that the French measures breached different provisions of the SPS and the TBT, and the GATT Articles III:4 and XI. The European Commission replied that substitute materials had been developed which were safer to human health than the carcinogenic asbestos used before. It insisted that the French measures were fully justified for public health reasons under GATT Article XX(b). Canada argued for a broad interpretation of 'like product' under the GATT, with an additional claim under the TBT Agreement. ${ }^{137}$

The panel in EC-Asbestos in the first instance separated the measure into the ban and the exceptions to that ban. It found that the French

\footnotetext{
135 US-Shrimp Article 21 (n 113) paras 136-48.

136 See eg Porges and Trachtman (n 64) 794; JP Trachtman, The International Economic Law Revolution and the Right to Regulate (Cameron May 2005) 141-142; G Marceau and JP Trachtman, 'A Map of the WTO Law of Domestic Regulation of Goods' in GA Bermann and PC Mavroidis (eds), Trade and Human Health and Safety (CUP 2006) 62

${ }^{137}$ See also WTO, 'WTO Dispute Settlement: One-Page Case Summaries' (2012) 54 <http:// www.wto.org/english/tratop_e/dispu_e/cases_e/ds135_e.htm> accessed 15 May 2014.
} 
ban was not covered by the TBT, whereas the immunities under TBT Article 2 were potentially applicable. ${ }^{138}$ However, as Canada had not made separate claims with respect to the ban's immunities under the TBT on public interest grounds, the panel declined to examine their compatibility with the TBT. ${ }^{139}$ Instead, the panel found a violation of NT under GATT Article III:4, given that the ban specifically treated chrysotile asbestos fibre less favourably than 'like' substitute fibre, and products containing chrysotile asbestos fibre were treated less favourably than 'like' products containing substitute fibre. ${ }^{140}$ The panel established that the measure was justified on the grounds of the exception of human health protection in accordance with GATT Article XX(b), and also fulfilled the conditions set out in the chapeau. ${ }^{141}$

The AB, having rejected the panel's reasoning that the ban was not covered by the TBT, whereas the exceptions under TBT Article 2 were potentially applicable, reversed the panel's decision and concluded that the ban as an 'integrated whole' was a TR as defined in TBT Annex 1.1 and was thus covered by the TBT; nevertheless, and astonishingly, the AB did not complete the legal analysis of Canada's TBT claims as it judged that it did not have an 'adequate basis' upon which to examine them. ${ }^{142}$

It is important to highlight several crucial interpretive points of the $\mathrm{AB}$ report in EC-Asbestos. First, the AB laid down the general interpretative guidelines for the term 'technical regulation': (i) the products subject to the measure in question must be identifiable; (ii) a measure must wholly lay down product characteristics or their related PPM; and (iii) compliance with the measure must be mandatory. ${ }^{143}$

Second, while reversing the panel decision, the AB introduced the well-known and widely cited set of factors for the definition of like products' for the purposes of GATT Article III:4 that focuses on the competitive relationship between imported and domestic products, largely drawing on the Border Tax Adjustments market-based criteria. ${ }^{144}$ It should be recalled that they are: physical properties, end use, consumer tastes and habits, and tariff classification. When reversing the panel's ruling to exclude health effects from the 'likeness' test, the AB found that panels must analyse the physical characteristics of products that affect the competitive relationship in the marketplace, including health risks. ${ }^{145}$

\footnotetext{
${ }^{138}$ European Communities - Measures Affecting Asbestos and Products Containing Asbestos [ECAsbestos]: Report of the Panel (18 September 2000) DS135, paras 8.63 and 8.70.

139 EC-Asbestos (n 138) para 8.72.

140 ibid, paras 8.157-158.

141 ibid, paras 8.223 and 8.240.

142 EC-Asbestos (n 11) paras 64-70, 74-75, 80.

143 ibid, paras 66-70.

144 GATT Working Party Report (n 66).

${ }^{145}$ EC-Asbestos (n 11) para 100.
} 
Third, while being clear about the factors for the specific marketbased 'likeness' test, the overall AB perspective regarding the 'like' products analysis when a public interest regulation is at issue was somehow ambivalent. Porges and Trachtman point to an inconsistency between this $\mathrm{AB}$ approach and the theory of regulation, which states that the reason for regulatory intervention is because the health risks are not sufficiently reflected in the marketplace. ${ }^{146}$ However, the AB has not brought the more regulation-sensitive 'aim and effects' test into its review of the panel's 'likeness' analysis; as long as health risks are consistent with regulatory concerns, the $\mathrm{AB}$ has accepted some considerations that form the basis of regulatory 'aims'. ${ }^{147}$

The EC-Asbestos decision, together with US-Shrimp, indicated that trade jurisprudence has shifted towards the more balanced interpretation and application of public policy exceptions under the GATT $1994 .{ }^{148}$ Moreover, in these three WTO cases, namely, US-Gasoline, US-Shrimp, and EC-Asbestos, the $\mathrm{AB}$ postulated the basic principles of interpretation of the GATT public policy exceptions.

Overall, such a turn suggests that the AB is a 'reflexive institution', ${ }^{149}$ attentively listening to critiques about its interpretive approaches, hence also about the WTO collective habits of interpretation, ${ }^{150}$ reflecting on these and evolving together with global trends and fashions, as well as those internal to the GATT/WTO regime.

To summarise, a deliberate decision of the GATT panels in the first two Tuna cases to push the PPM issue out of the orbit of trade law appears as an effort, at least among other things, to maintain a sort of normative hierarchy of the GATT regime by giving no autonomous importance to the particular issue of good process, and the environment more generally. I presume that this move of the GATT in the early 1990s contributed to the abandonment of the issue of good process and the overall regulation of the environment within global commercial and investment flows to other realms of global governance traditionally deemed as 'private' (eg contracts, indicators, labelling, and, of course, voluntary standards such as ISO). I then suppose that, when the WTO judicial bodies, particularly the $\mathrm{AB}$, later included the PPM in first-row considerations regarding 'like' products under different WTO agreements, including TBT jurisprudence, it was a - conscious or unconscious - move to bring the regulation of the process of production back within the realm of its global jurisdiction.

\footnotetext{
146 Porges and Trachtman (n 64) note 56.

147 ibid , 795.

148 In this sense, see eg Schneiderman (n 133) 66.

149 ibid.

${ }^{150}$ I met this concept for the first time, in Lang (n 72). See eg at 170-171, 179, 181, 185.
} 
Otherwise, it may also reveal that the $\mathrm{AB}$ may be cautious about the overall legitimacy of the world trade regime, in terms of caring not only about the structural unity and normative coherence of its legal organisation, but also about the wider social perception of the GATT/WTO.

\section{The WTO's technical barriers to trade (TBT) agreement}

The TBT aims at providing equilibrium between the autonomy of national regulation and the policy goals of trade liberalisation. ${ }^{151}$ More precisely, TBT disciplines are designed to deliver a legal framework for state regulations constituting non-tariff measures (NTMs) such as human safety and health, plant life and health, prevention of deceptive practices, and environmental protection. ${ }^{152}$ In trade jargon, the term 'NTMs' designates non-tariff policy measures that can potentially affect trade in goods. ${ }^{153}$

At the outset, on a potential objection that such domestic instruments are already governed by the GATT national treatment provisions of Article III:4, (or else those of MFN, GATT Article I; transparency, GATT Article X; quantitative restrictions GATT Article XI) and, consequently, by the GATT public policy exception clauses of Article XX, the answer is that the TBT governs the so-called technical regulations, standards, and conformity assessment measures. That is, these instruments deal with the methods relating to the process of the production of imported and domestic goods: labelling requirements, safety requirements for cars, recycling requirements on packaging, and the like. They are aimed at a variety of ends, from informing the consumer about the composition of a product to putting conditions on the market access of imported goods. Notably, on the one hand, today we face a proliferation of such public policy NTMs. On the other hand, public health and the environment are areas where the regulatory process goes hand in hand with technical innovation. That is, regulation at the domestic level is increasingly affected by efficiency concerns, such as necessity, scientific justification, procedural legitimacy, and consistency, resulting from pressure from internal lobbies through the coordination at the international level, and the creation of international standards. ${ }^{154}$ The TBT thus contains various disciplines on state regulatory processes, requiring an important degree of transparency, coherence, and consistency in regulation to assure trad-

\footnotetext{
${ }^{151}$ MJ Trebilcock, 'Foreword' in T Epps and M J Trebilcock (eds), Research Handbook on the WTO and Technical Barriers to Trade (Edward Edgar 2013) xi.

${ }^{152}$ See WTO, 'Technical Information on Technical Barriers to Trade' < http://www.wto.org/ english/tratop_e/tbt_e/tbt_info_e.htm>

${ }^{153}$ For a definition, see eg WTO, The World Trade Report 2012: Trade and Public Policies: A Closer Look at Non-tariff Measures in the 21st Century (WTO Publications 2012), 38ff.

${ }^{154}$ Hoekman and Kostecki (n 2) 462-465; Mavroidis et al (n 1) 263; Lang (n 72) 159.
} 
ing partners that protectionism is not rooted at some deep level in the regulatory process. ${ }^{155}$

But first things first: before delving into an analysis of the relevant TBT disciplines and case law, as well as the normative considerations underpinning them, the following sections primarily sketch the fundamentals and relevant historical and conceptual developments of the TBT framework.

\subsection{The fundamentals of the TBT}

On plain reading of the above introduction of the TBT, the agreement is supposed to disentangle the possible trade-distorting effects from the trade-facilitating aspects of NTMs by binding WTO members to guarantee that technical regulations and product standards do not constitute unnecessary barriers to trade. ${ }^{156}$

It is argued that the TBT regime aims at solving the conflict between the two kinds of opposite effects of domestic regulations by separating 'protectionist' standards from 'legitimate' ones. ${ }^{157}$ The normative framework within which TBT untangles the two consists of two fundamentals: standards harmonisation on the one hand, and the administrative process that precedes the creation and implementation of national technical regulations on the other. ${ }^{158}$

The rationale of the first fundamental is the conviction that a more homogenous technical regulation at the global level can diminish the number of transnational risk disputes, and, by creating a network of homogenised standards, would provide the WTO with a mechanism for disentangling legitimate standards from protectionist ones. ${ }^{159}$ Accordingly, the WTO supports the creation of standards within several global standard-setting institutions, including the IEC, ISO, and the like. ${ }^{160}$

\footnotetext{
155 See generally, R Howse, 'Democracy, Science and Free Trade: Risk Regulation on Trial at the World Trade Organization" (2000) University of Michigan Law Review, 2329, as cited in R Howse and E Tuerk (2001), "The WTO Impact on Internal Regulations: A Case Study of the Canada-EC Asbestos Dispute' in G de Búrca and J Scott (eds), The EU and the WTO: Legal and Constitutional Issues (Hart Publishing) 286.

156 TBT Preamble, 5th and 6th recitals.

157 Perez (n 85) 116.

158 ibid 116-117.

159 ibid.

160 Overall, ISO collaborates with over 700 international, regional and national organisations that take part in the standard setting and development process, as well as sharing expertise and best practices. The ISO has observer status at the FAO Codex Alimentarius Commission and in the TBT Committee. It is expressly referred to in the WTO SPS and TBT Agreements (the latter using the ISO/IEC Guide for a definition of some matters). ISO, Organizations in Cooperation with ISO <http://www.iso.org/iso/home/about/organizations_in_liaison.htm> accessed 17 March 2015.
} 
The second fundamental is driven by the aim to discipline the administrative process by which technical regulations are introduced. ${ }^{161}$ One of the central tools for this task is the technocratic, scientific, assessment of the creation and design of a regulation: ${ }^{162}$ ie the two external sources, international standards and science, seem to have the ultimate verdict over the distinction between legitimate and protectionist technical regulations, turning it into a functional legal conception. The apotheosis of this approach is actually the test under TBT Article 2.2, where the efficiency and risk management metaphors, such as necessity, scientific justification, procedural legitimacy, and consistency may play a crucial role. ${ }^{163}$

\subsection{The main TBT disciplines}

The introduction of the concepts of the domestic regulation of social imperatives, and NTMs properly speaking, to world trade law deserves particular attention here. According to influential mainstream commentators of the world trade regime, roughly, NTMs (or 'non-tariff barriers', or 'regulatory trade barriers') fall into one of three broad categories: (i) regulatory protectionism, ie measures purportedly concerned with consumer protection, or other policy purposes, but with a component that could be utilised to favour domestic producers; (ii) regulatory divergence, ie regulatory differences across countries, arising either arbitrarily or based on different regulatory traditions and preferences; and (iii) regulatory reform, ie measures aiming at improving the regulatory process or the efficiency of regulation. ${ }^{164}$ And if it is not one of these three issues, it is contended that the measure should not be seen as a barrier distorting trade. To these I would add the category of 'regulatory inadequacy', ie a public policy regulation could be irrelevant or simply inapt to adequately meet the corresponding objectives set, hence, as a side effect, also possibly distorting trade. On the other hand, regarding WTO member state appreciation, Robert Howse assumes that there is no natural or self-

\footnotetext{
161 Perez (n 85) 117.

162 ibid.

${ }^{163}$ See eg R Howse's 'WTO Seals: What Is It Really That Makes the AB Think that TBT Doesn't Apply?' (International Economic Law and Policy Blog, 25 May 2014) <http:// worldtradelaw.typepad.com/ielpblog/2014/05/wto-sealswhat-is-it-really-that-makes-theab-think-that-tbt-doesnt-apply.html> accessed 15 December 2015; Perez (n 85) 115-121; S Lester, 'Technical Barriers to Trade (Technical Regulations \& Standards)' (Presentation made at the Academy of WTO Law and Policy, Institute of International Economic Law, Georgetown University Law Center, Washington, DC 19 November 2013).

${ }^{164}$ S Lester, 'Regulatory Cooperation in the TTIP / Regulatory Trade Barriers' (International Economic Law and Policy Blog, 17 December 2013) < http://worldtradelaw.typepad.com/ ielpblog/2013/12/regulatory-cooperation-in-the-ttip.html > accessed 1 April 2015. See also S Lester and I Barbee, 'Regulatory Trade Barriers in the Transatlantic Trade and Investment Partnership' (2013) Journal of International Economic Law 1; World Trade Report (n 153) 5.
} 
evident baseline or rule that can solve' what should and what should not fall into the category of a regulatory trade barrier. ${ }^{165}$

In practice, relevant NTMs are the key trade instruments governed by the TBT: ie technical regulations (TRs). The second key trade instrument covered by the agreement is standards. Both set out specific characteristics of a product (size, shape, design, functions, performance, etc), hence the way a product is produced can affect these characteristics. ${ }^{166}$ A principled difference between a TR and a standard lies in compliance: while compliance with TRs is mandatory, because regulations are themselves binding instruments, conformity with standards is not, the latter being voluntary mechanisms. ${ }^{167}$

Whereas the TBT definition of the TR is relatively ambiguous, the substantive obligations that the agreement imposes are rather straightforward: Article 2.1 contains NT and MFN obligations, while Article 2.2 states that TRs should not be unnecessary obstacles to trade. ${ }^{168}$ Interestingly, specialists say that during the talks over the TBT substantive obligations text, the negotiators eventually shifted from terms like 'serious' (eg 'serious barrier to trade') to the vocabulary of 'necessity' (eg 'more trade-restrictive than necessary'). ${ }^{169}$ This remark is very useful for an analysis of relevant case law and subsequent normative understanding of the AB's interpretive choices, and will be taken up further in the article.

The TBT also covers conformity assessment procedures. These are technical procedures, eg testing, verification, inspection and certification that confirm that products fulfil the requirements laid down in regulations and standards. ${ }^{170}$ Regarding the operation of standards, the same non-discrimination obligations as above are stipulated in TBT Annex 3 (D), and, regarding the operation of conformity assessment, in TBT Article 5.1.1.

The main objectives of both TRs and standards covered by the TBT are the protection of human safety or health (eg labelling of cigarettes to indicate that they are harmful to health); the prevention of deceptive practices (eg labelling or packaging requirements in order to protect

\footnotetext{
165 'Individual member states' perceptions of what policies fall on one side of the line and what on the other are going to vary depending on ideology, regulatory traditions, and so forth, all of which generate intuitions about whether someone's regulatory behavior looks like "normal" public policy or, rather, like something that might only be done in the circumstances for protectionist reasons.' R Howse, 'From Politics to Technocracy - and Back Again: The Fate of the Multilateral Trading Regime' (2002) 96 American Journal of International Law 94, 104.

166 Mavroidis et al (n 1) 264-266; Guzman and Pauwelyn (n 3) 523; see also WTO (n 152).

167 Mavroidis et al (n 1); Guzman and Pauwelyn (n 3).

168 Guzman and Pauwelyn (n 3) 524.

169 Lester (n 163).

170 WTO (n 152); Guzman and Pauwelyn (n 3) 523.
} 
consumers through information); the protection of animal/plant life or health (eg requiring that endangered species of fish reach a certain length before they can be caught); and the protection of the environment (eg regulating the re-cycling of paper and plastic products, or the levels of motor vehicle emissions). ${ }^{171}$ Other objectives may include quality (eg requiring that vegetables and fruits reach a certain size to be marketable) and technical (eg harmonising certain sectors, such as telecommunications) harmonisation, or trade facilitation (eg harmonising customs equipment). ${ }^{172}$

As mentioned earlier, the trade measures covered by the TBT deal, among other things, with methods relating to the process of the production of imported and domestic goods. ${ }^{173}$ In trade jargon, these are called 'process and production methods' (PPM). ${ }^{174}$ Let me recall that the general importance of the PPM issue vis-à-vis trade law is whether the 'like' products with a different PPM could be treated differently by the parties to the world trade regime. PPMs could be divided into two categories: productrelated PPMs and non-product-related PPMs.

\section{Relevant TBT jurisprudence}

It has already been mentioned above that until very recently the TBT has been a rather 'dormant' WTO agreement, and has been interpreted only once - in 2002 in the case EC-Sardines. ${ }^{175}$ Since 2009, however, consultations have been requested, and subsequently three disputes have been brought to the WTO DSB (US-Clove Cigarettes, ${ }^{176}$ US-Tuna II

\footnotetext{
${ }^{171}$ WTO (n 152).

172 ibid.

173 TBT Annex 1.

${ }^{174}$ For a very nuanced account of PPM in GATT/WTO law, see R E Hudec, "The ProductProcess Doctrine in GATT/WTO Jurisprudence' in Bronckers and Quick (n 68) $187 \mathrm{ff}$.

175 The EC Regulation (EEC) 2136/89 for the European common market standards on preserved sardines specified that only products prepared from Sardina pichardus species could be marketed/labelled as 'preserved sardines'. Following this, while the species of sardines found mainly in the Eastern North Atlantic, in the Mediterranean Sea and the Black Sea (so, mainly in Europe), Sardina pilchardus Walbaum, were tradable under the EC regulation, the Sardinops sagax sagax, found mainly in the Eastern Pacific along the coasts of Peru and Chile, were not tradable under this regulation. On such basis, Peru filed a complaint arguing that the policy stopped Peruvian exporters from using the trade description 'sardines' for their exports in Europe. In particular, Peru argued that, according to the relevant Codex Alimentarius standards, Sardinops sagax sagax is listed among those species that are marketable as 'sardines', including in Europe. It thus submitted that the above measure constituted an unjustifiable NTB by breaching GATT Article XI: 1 and TBT Articles 2 and 12. WTO, 'European Communities - Trade Description of Sardines' < http://www. wto.org/english/tratop_e/dispu_e/cases_e/ds231_e.htm $\geq$ accessed 1 September 2015; see also WTO, 'WTO Dispute Settlement: One-Page Case Summaries 1995 - 2011' (2012) 91.

176 This dispute concerned Section 907(a)(1)(A) of the Federal Food, Drug and Cosmetic Act (FFDCA). This measure, while outlawing the production and distribution of clove cigarettes,
} 
(Mexico), ${ }^{177}$ and US-COOL), all of which have fully engaged the TBT. All three cases have reached the stage of appeal, and in 2012 the AB finalised its three reports. One of the three decisions, namely US-COOL, was followed in 2014 by a compliance panel hearing, where the panel had to establish whether the US had taken the necessary steps to implement the decision. The panel's ruling was appealed by Canada and Mexico, and in May 2015 the AB issued its US-COOL Article 21.5 report. In this report, the WTO AB, while weighing the necessity of the regulation in question, raised the notion of margin of appreciation. In this article, the above interpretative development represents the apotheosis of the interest of the part on the WTO law analysis.

In the sections that follow, I will first briefly introduce the US-COOL row of disputes. Then, instead of analysing TBT cases in chronological order, I will track one, some or all of them (together with previous relevant disputes where needed) per relevant issue, while focusing especially on the last AB report - the COOL Article 21.5 dispute. The highlighted issues are various interpretive and normative considerations regarding the discrimination and necessity analyses under the TBT.

as well as most other flavoured cigarettes in the US, did not ban menthol-flavoured cigarettes. The vast majority of clove cigarettes consumed in the US prior to the ban were imported from Indonesia. Indonesia filed a complaint under the TBT (but not under the SPS!), arguing that the ban on clove cigarettes was a discriminatory NTM, and that it was also unnecessary. Indonesia further claimed that the US acted inconsistently with a number of procedural and similar requirements under the TBT (actually, almost all of the 12 paragraphs of TBT Article 2) in the context of preparing and implementing the TR in question. See US-Clove Cigarettes (n 12).

177 The US argued that for years, in Eastern Tropical Pacific Ocean tuna fishery, dolphins were an intrinsic part of the fishing operation; the fishermen would intentionally capture both tuna and dolphins together, then release the dolphins from the net - some dolphins were released alive, and some were not. In the tropical waters of the Pacific Ocean west of Mexico and Central America, large yellowfin tuna (Thunnus albacares) swim together with several species of dolphins: while this ecological association of tuna and dolphins is not clearly understood, it is asserted to have two important practical consequences - (i) it has formed the basis of a successful tuna fishery; and (ii) it has resulted in the deaths of a large number of dolphins. See US National Oceanic and Atmospheric Administration (NOAA)'s Southwest Fisheries Science Center Report 'The Tuna-Dolphin Issue' <https://swfsc.noaa. gov / textblock.aspx?Division=PRD\&ParentMenuId=228\&id=1408 $\geq$ accessed 1 September 2015; and WF Perrin, B Wursig and JGM Thewissen (eds), Encyclopedia of Marine Mammals (Academic Press 2002) 1269-1273. This was the main reason why the US regulations in the Eastern Tropical Pacific, where the Mexican fleet fishes, were far more restrictive than they were for the Western and Central Pacific where the US fleet fishes. Namely, the US Congress blocked tuna fished with purse-seine nets from the US market. Mexico claimed that the measures at issue that established the conditions for the use of a 'dolphin-safe' label on tuna products and that conditioned access to the US Department of Commerce official dolphin-safe label on the bringing of certain documentary evidence imposed a discriminatory burden on certain tuna, depending on where it was caught, and the fishing method by which it was harvested, thus were inconsistent, inter alia, with TBT Articles 2.1, 2.2 and 2.4. WTO, United States - Measures Concerning the Importation, Marketing and Sale of Tuna and Tuna Products (Dispute Settlement) <http://www.wto.org/english/tratop_e/dispu_e/ cases_e/ds381_e.htm> accessed 1 September 2015. 


\subsection{Overview of the US-COOL row}

COOL is the abbreviation for the US country of origin labelling requirements for beef and pork, as contained in the Agricultural Marketing Act of 1946. Instruments comprising the COOL measure were amended by the Farm Bills of 2002 and 2008, and implemented by the USDA through its 2009 Final Rule on Mandatory Country of Origin Labelling. There was also a letter issued by US Secretary of Agriculture Vilsack on the implementation of the COOL measure (Vilsack letter). The main requirements included the obligation to inform consumers at the retail level of the country of origin in respect of the covered commodities, including beef and pork. Eligibility for the designation of a covered commodity as exclusively having a US origin could only be derived from an animal that was exclusively born, raised and slaughtered in the US. This would exclude such a designation for beef or pork derived from livestock that was exported to the United States for feed or immediate slaughter. The COOL requirements in question were argued to breach, inter alia, TBT Articles $2.1,2.2$ and $2.4 . .^{178}$

Overall, in its original ruling, the $\mathrm{AB}$ upheld, but for different reasons, the panel's finding that the policies in question were in breach of TBT Article 2.1 by granting less favourable treatment to imported Canadian cattle and hogs than to like US cattle and hogs. ${ }^{179}$ The AB reversed the panel's finding that the COOL measure violated TBT Article 2.2 because its legitimate objective of providing consumers with information on origin was not fulfilled. ${ }^{180}$ It declared itself unable to complete the legal analysis and determine whether the COOL measure was more trade restrictive than necessary to meet its objective. ${ }^{181}$ Regarding international standards, the panel found that Mexico had failed to establish that the COOL measure violated TBT Article 2.4, and this has not been reversed by the AB. ${ }^{182}$ The panel concluded that CODEX-STAN 1-1985 was an inappropriate means for the fulfilment of the pursued objective because the exact information that the US wanted to provide to consumers, ie the countries where an animal was born, raised and slaughtered, could not be conveyed through this standard. ${ }^{183}$

In 2013, Canada requested the establishment of a compliance panel. At its meeting, the DSB deferred the establishment of a panel. This

\footnotetext{
${ }_{178}$ United States - Certain Country of Origin Labelling (COOL) Requirements [US-COOL],(25 September 2013) DS384 <https://www.wto.org/english/tratop_e/dispu_e/cases_e/ ds384_e.htm> accessed 1 March 2015.

179 US-COOL (n 12) paras 478-79.

180 ibid. para 479.

181 ibid. para 491.

182 ibid. para 485.

183 ibid. See also United States - Certain Country of Origin Labelling (COOL) Requirements [USCOOL): Report of the Panel (18 November 2011) DS384, para 7.567.
} 
case addressed whether the updated measure taken by the US in 2013 complied with the DSB recommendations and rulings in the original USCOOL dispute. Canada and Mexico challenged the treatment accorded to imported Canadian cattle and hogs, and imported Mexican cattle, under the US's amended COOL rules for beef and pork. This amended COOL measures consisted of: (i) the 'COOL statute' (7 U.S.C. § 1638), which remained unchanged from the original dispute; and (ii) the '2013 Final Rule' (78 Fed Reg 31367) amending certain provisions of the 2009 Final Rule (74 Fed Reg 2658) following the original dispute. ${ }^{184}$ The compliance panel US-COOL Article 21.5 was then established. ${ }^{185}$ The panel's decision was appealed, and on 18 May 2015 the AB issued its report. Regarding TBT Articles 2.1 (discrimination) the AB upheld the panel; and regarding Article 2.2 (necessity), it made no finding as to whether the amended COOL measure was inconsistent with Article 2.2, though placing a nuance on a few points that are crucial for the present analysis. For example, the $\mathrm{AB}$ stated:

...we do not consider that a complainant must demonstrate that its proposed alternative measure achieves a degree of contribution identical to that achieved by the challenged technical regulation in order for it to be found to achieve an equivalent degree. Rather, in our view, there is a margin of appreciation in the assessment of whether a proposed alternative measure achieves an equivalent degree of contribution, whose contours may vary from case to case. In particular, $a$ margin of appreciation in assessing the equivalence of the respective degrees of contribution may be affected by the nature of the risks and the gravity of the consequences arising from the non-fulfilment of the technical regulation's objective... ${ }^{186}$

That is, the $A B$ pointed out that the panel must have assessed the risks of non-fulfilment, and the role of the legitimate objective, as these criteria would affect the application of a margin of appreciation that national regulators benefit from. These factors, as well as the related principles and interpretive criteria will be discussed in the remainder of this article by analysing US-COOL Article 21.5 and other decisions under the $T B T$, as well as relevant interpretive moments under the GATT.

${ }_{184}$ WTO, Appellate Body Reports <https://www.wto.org/english/tratop_e/dispu_e/ab_ reports_e.htm $\geq$ accessed 1 March 2015.

${ }^{185}$ United States - Certain Country of Original Labelling (COOL) Requirements - Recourse to Article 21.5 of the DSU by Canada and Mexico [US-COOL Article 21.5] (20 October 2014) DS 384 and 386.

186 US-COOL Article 21.5 (n 12) para 5.254 (emphasis added). 


\subsection{The same, the same, but different (and how is it different from ECtHR's margin of appreciation?): more deference under the TBT than under the GATT}

The first puzzling question is why the AB seems to do a more deferential analysis under the TBT non-discrimination provisions than under the GATT ones. ${ }^{187}$ The broad preamble of the TBT justifies this deference, but does not the chapeau of GATT Article XX do so as well? Furthermore, domestic regulations are limited by a 'necessity' test that is applicable to certain regulatory measures under both GATT Article XX(b) and TBT Article 2.2. Both provisions require that states use the least trade restrictive means reasonably available, although the TBT necessity test is considered to be broader than the obligation under GATT, as it requires that all measures falling under the TBT, whether or not discriminatory, should be no more trade restrictive than necessary. ${ }^{188}$ As neither agreement requires a clearly scientific basis as a foundation for the conflicting measure, states may have more discretion as to the choice of the end to pursue in comparison with the SPS measures; however, the importance of the end comes into the test of 'necessity' in both GATT and TBT through the risks of non-fulfilment of the objective pursued. ${ }^{189}$ Hence, we have the necessity test under both GATT (Article XX(b)) and the TBT (Article 2.2), additional necessity requirements in the chapeau of GATT Article XX and the similar least restrictive means test in the TBT preamble. In US-Clove Cigarettes, for instance, there was no additional deferential enquiry under GATT Article III:4 in the AB ruling.

Another interesting question is why the $\mathrm{AB}$ did not use in its three 2012 TBT reports the concept of good faith that it introduced in USGasoline and clarified in US-Shrimp? Notably, the second recital of the TBT Preamble says that the TBT should 'further the objectives of GATT 1994'. In US-Clove Cigarettes, the WTO DSB explained the above issues of relationship and equilibrium between the goals of the GATT and the TBT as follows. It held that, while there was in TBT a set of obligations supplementary to those of the GATT, the TBT should be applied so as to preserve the same kind of balance between free trade goals and the members' regulatory policy space reflected in the 'right to regulate' in GATT:

[t]he balance set out in the preamble of the TBT Agreement between, on the one hand, the desire to avoid creating un-

\footnotetext{
187 Notably, this was the case for the three 2012 TBT rulings discussed above, as well as in US-COOL Article 21.5.

${ }^{188}$ In this respect, see eg Marceau and Trachtman (n 136) 811ff; AJ Green, 'Climate Change, Regulatory Policy and the WTO: How Constraining are Trade Rules?' (2005) 8(1) Journal of International Economic Law, available at SSRN <http://ssrn.com/abstract=702444> accessed 10 October 2015.

${ }^{189}$ Green (n188) 49.
} 
necessary obstacles to international trade and, on the other hand, the recognition of Members' right to regulate, is not, in principle, different from the balance set out in the GATT 1994, where obligations such as national treatment in Article III are qualified by the general exceptions provision of Article XX (my emphasis). ${ }^{190}$

Here I would like to emphasise that the 'balance' set out in the TBT and the GATT which the AB underlines does not mean balancing between two set of values - at least not in the way that the ECtHR or a national administrative tribunal would use it. Namely, 'balancing' members' rights to freedom of trade against the recognition of members' right to regulate, or else to set their own levels of protection, is not at all the same as balancing the members' trade-related rights protected under the WTO agreements and members' pressing social needs. The former is about balancing the rights to free trade protected by the WTO agreements against members' measures restricting trade when setting their own level of protection. This line is clearly - and increasingly - practised by WTO judges, especially the AB. However, the latter is about balancing the objective pursued by a state measure restricting the rights protected by the ECHR against the legitimacy of the measure itself. This approach used by the ECtHR was never properly applied within the world trade regime adjudication. Note, however that the 'means-end' test under GATT Article XX was held by the AB in USShrimp, implying that measures must be expressly designed to contribute to attaining a legitimate objective. So, the substantive application of the measure in practice was somehow balanced by the AB in this case in the chapeau analysis against the form in which it was designed on paper.

It is worth noting that in US-COOL Article 21.5, the AB seems to take yet another stance. Namely, the assessment concerned the hypothetical impact in the case of the non-fulfilment of a regulation in the context of a necessity analysis. ${ }^{191}$ That is, as already noted in US-Gasoline, the effects attributable to implementation should be distinguished from the implementation itself. Now let us recall that in US-Clove Cigarettes the AB stressed that the TBT should be interpreted so as to preserve the same kind of balance as the GATT between free trade goals and members' regulatory policy space, that is, their right to regulate. ${ }^{192}$ However, in USCOOL Article 21.5, the AB now decided that

\footnotetext{
190 US-Clove Cigarettes (n 12) para 182.

191 US-COOL Article 21.5 (n 12) paras 5.277-79; 5.295-296.

192 'The balance set out in the preamble of the TBT Agreement between, on the one hand, the desire to avoid creating unnecessary obstacles to international trade and, on the other hand, the recognition of Members' right to regulate, is not, in principle, different from the balance set out in the GATT 1994, where obligations such as national treatment in Article III are qualified by the general exceptions provision of Article XX...', US-Clove Cigarettes (n 12) para 182.
} 
a technical regulation itself, or its associated instruments, may reveal elements relevant to the nature and gravity of the risks addressed. However, the Panel did not consider the evidence and argumentation presented by Canada and Mexico to substantiate the connection between specific aspects of the design, architecture, and structure of the amended COOL measure, on the one hand, and the nature of the risks of the non-fulfilment of its objective or the gravity of the consequences arising from its non-fulfilment, on the other hand. ${ }^{193}$

So, here it is not a WTO-type of balancing between free trade goals and members' right to regulate. That is, following the US-Gasoline ruling, the effects attributable to implementation should be connected with, yet distinguished from, the implementation itself. This type of reasoning is not exactly the same as balancing the objective pursued by a measure against the legitimacy of the measure itself. However, while in US-COOL Article 21.5 the AB clearly does not assert that the objective, design, and structure of the measure are worth the measure itself, it seems to suggest here that the panel should have considered whether the objective, design, and structure of the measure are worth the gravity of the consequences arising from its non-fulfilment. That is, instead of enquiring whether the aim of the measure is legitimate enough to deem this very measure legitimate (which would have been a proper balancing), the AB seems to look at what would happen if the measure was not applied and its objectives were not reached.

In US-COOL Article 21.5, the AB appears to make two distinctions. Firstly, it seems to make an interpretation distinct from relevant points in the earlier GATT jurisprudence regarding the right to regulate. Secondly, and in relation with this, the $\mathrm{AB}$ seems to make an interpretation distinct from applicable accounts in the preceding TBT jurisprudence, that is, to balance the conceptions very different from the three TBT cases of 2012: instead of weighing free trade obligations and the right to regulate, it balances the design of the measure, the nature of the risks of the nonfulfilment of its objective, and the gravity of the consequences arising from its non-fulfilment. That is, it somehow echoes two of the four criteria of the overall proportionality test in ECtHR jurisprudence related to the MoA, mentioned above in Section 1.3.2: (i) the reasons presented by the authorities should be relevant and sufficient and the means-end test should be satisfied - viz, the measure should be a proportionate response to the need; ${ }^{194}$ and (ii) the effects of the treatment should be proportion-

\footnotetext{
193 US-COOL Article 21.5 (n 12) paras 5.286 (emphasis added).

194 Abdulaziz (n 53) paras 74-84. See also Malone $v$ The United Kingdom (1984) 7 EHRR 14; Silver $v$ The United Kingdom (1983) 5 EHRR 347; Sunday Times $v$ The United Kingdom (1979) 2 EHRR 245; Muller v Switzerland (1988) 13 EHRR 212; and Vereinigung Demokratischer Soldaten Osterreichs und Gubi v Austria (1994) ECHR 50.
} 
ate in relation to the pursuit of the policy objective and should manage to strike an equilibrium between the protection of the interests of the community and respect for the rights and freedoms safeguarded by the Convention. ${ }^{195}$ That is, the strict proportionality test involves, among other things, assessing whether the reasons presented by the government are relevant and sufficient, and balancing between pressing social need for some restriction of the Convention, and a proportionate response to that need through a particular policy or behaviour of the authorities.

Furthermore, the following $\mathrm{AB}$ remark in the most recent decision points to a further assumption:

A technical regulation itself, or its related instruments, might contain elements pertaining to the nature of the risks it seeks to address and the gravity of the consequences arising from the non-fulfilment of its objective. ${ }^{196}$

We can understand by this that national regulators may themselves know very well the nature of the risks they aim to address and the gravity of the consequences arising from the non-fulfilment of the objective of their regulation. So, I presume this could be an assertion of greater deference to domestic regulators - in the sense that they are competent enough to discern and bear the importance and/or legitimacy of the aim pursued by a regulation.

\subsection{Ranking in favour of one value: market competition and how it is dismissed in US-COOL 21.5}

Both GATT Articles III and XX and the relevant provisions of the TBT agreement deal with the justification of domestic regulatory measures other than fiscal ones (the latter are decided by GATT Article III:2), as related to legitimate (non-protectionist) objectives and as the least traderestrictive alternative reasonably available. Regarding the competition analysis of domestic non-fiscal regulatory measures, we should recall that the 'like products' test is based on the four criteria set forth in Border Tax Adjustments ${ }^{197}$ and essentially endorsed by the panel in EC-Asbestos. Namely, in examining 'likeness', the panel considered only factors that were decisive for a competitive relationship between the imported and domestic goods in the domestic market-place: physical characteristics, end use, consumer tastes and habits, and tariff classification. ${ }^{198}$ This

\footnotetext{
195 Belgian Linguistic case (n 30) paras 34-35.

196 US-COOL, Article 21.5, para 5.284.

197 GATT Working party report (n 66) 97. See also Hudec (n 65) 113.

198 Notably, the EC said that substitute materials had been developed in place of asbestos a highly carcinogenic substance - which are safer to human health. The panel, in using only an economic competitive comparisons test (see Panel Report, 8.112ff), found that the French
} 
logic of basic economics of the panel in EC-Asbestos was extensively criticised and was required to be balanced with a regulatory context and intent approach, which can be equally found in international investment arbitration. ${ }^{199}$ That is, the de facto discrimination issue appeared in the EC-Asbestos dispute, and the AB's decision settled some of the old arguments, while correcting an odd panel ruling. ${ }^{200}$ In deciding this dispute, the panel rejected the regulatory context and intent approach in concluding that health considerations should be irrelevant in determining whether products are 'like' for purposes of assessing domestic regulations; however, the $\mathrm{AB}$ reversed such an approach. ${ }^{201}$

In the EC-Asbestos case, the $\mathrm{AB}$ affirmed that the basic purpose of GATT Article III is the discipline of non-discrimination, not that of market access as such - ie it aims at restraining protectionist measures. ${ }^{202}$ Nonetheless, the AB also accepted the relevance of applying market competition criteria to 'likeness' in cases such as EC-Asbestos, rather than considering properly regulatory purposes such as protection of health. ${ }^{203}$ Thus, according to the AB, the panel erred not in the application of such criteria, but in assuming that in so doing factors such as effects on health could be excluded from the economic analysis. ${ }^{204}$ Consequently, on the one hand, in the EC-Asbestos dispute the $\mathrm{AB}$ did not advocate a regulatory context and intent approach to complement the purely economic analysis primarily looking at consumer and market preferences - quite the contrary, it opted to rely on 'objective' economic evidence, survey data, and a cost-benefit analysis as an indication of the non-discrimination norm. ${ }^{205}$ On the other hand, however, the $\mathrm{AB}$ also accepted that the defence of legitimate regulation in disputes concerning NT requires attention to be given to the purpose of a challenged regulation, not just a formalistic analysis based on the Border Tax Adjustments criteria. ${ }^{206}$ All

measures were discriminatory, but justified for public health reasons under GATT Art. XX (b), while the AB reversed this panel finding (AB Report, para 109ff), and stressed that the French measures were not discriminatory, and were fully justified for public health reasons under GATT Article XX (b) (see eg para 172, quoting the Korea-Beef ruling).

199 For a general overview see A Newcombe and L Paradell, Law and Practice of Investment Treaties, Standards of Treatment,(Wolters Kluwer 2009); M Sornarajah, The Pursuit of Nationalized Property (Nijhoff Publishers 1986); and M Sornarajah The International Law on Foreign Investment ( $4^{\text {th }}$ edn, CUP 2015).

200 Porges and Trachtman, (n 64) 794.

201 EC-Asbestos (n 11) paras 99, 109, 114, 117, 122-124.

202 Howse and Tuerk (n 155) 292; Lang (n 72) 260-62.

203 Although, in EC-Asbestos, one member of the AB, Justice Feliciano, did not agree with the use of the 'like products' test involving only economic competitive comparisons in cases involving such key human values as life and health. See EC-Asbestos (n 11) paras 149 and 152-154.

${ }^{204}$ Howse and Tuerk (n 155) 288.

205 In this sense, see Lang (n 72) 262.

206 Porges and Trachtman (n 64) 785-86. 
in all, I rather agree that it is perfectly understandable that the panel's reasoning (finding that a legitimate domestic regulation aiming at protecting humans from the harm of a carcinogenic product may be 'discriminatory' according to an 'objective' market-based analysis) could be intuitively unappealing ${ }^{207}$ - for most of the litigators, WTO members, academia, and the wider public. That is, I think this is the main reason why the AB had so bluntly criticised the panel and eventually reversed its ruling. Yet, it ultimately accepted the relevance of market competition criteria for the 'likeness' test in cases relevant for health measures without paying much attention to regulatory aims and context factors.

The above competitive relationship test involving essentially economic comparisons between an imported and domestic group of goods in the domestic market now seems to be somewhat confirmed in US-Clove Cigarettes regarding the analysis under TBT Article 2.1. That is, in its report, the AB rejected the panel's regulatory aims and effects approach. ${ }^{208}$ In US-Clove Cigarettes, contrary to the EC-Asbestos ruling, the AB focused on market competition and applied the market-based test. Joost Pauwelyn posed questions in this respect as follows: "whom should we ask to see whether products, here sub-groups of cigarettes, sufficiently compete?'209 First, 'not only ... the main consumers of clove and menthol cigarettes, particularly where it is clear that an important proportion of menthol cigarette smokers are adult consumers', but all relevant consumers of the products at issue were considered by the AB. ${ }^{210}$ Further, the $\mathrm{AB}$, in using the data of a survey conducted only in respect of a segment of consumers, that is, young smokers, concluded that 'young and potential young smokers perceive clove and menthol cigarettes as sufficiently substitutable. This, in turn, is sufficient to support the Panel's finding that those products are like' (emphasis added); 211 'actual competition does not need to take place in the whole market, but may be limited to a segment of the market'. ${ }^{212},{ }^{213}$

Another crucial issue for the non-discrimination analysis was the term 'menthol', viz the competitive relationship seems to be seen through just clove articles versus menthol articles. It was the term 'menthol' then that was the root of the detrimental impact assessment under TBT Article

\footnotetext{
207 Lang (n 72) 264.

208 US-Clove Cigarette (n 12) para112.

${ }^{209}$ See J Pauwelyn, 'Questions on Impact of Cloves on GATT National Treatment' (International Economic Law and Policy Blog, 6 April 2012) < http://worldtradelaw.typepad.com/ ielpblog/2012/04/questions-on-impact-of-cloves-on-gatt-national-treatment.html> accessed 1 April 2015.

210 US-Clove Cigarette (n 12) para 137.

211 ibid, para 144.

212 ibid, para 143.

213 See Pauwelyn (n 209).
} 
2.1. Interestingly, on the question concerning what if menthol had been included in the regulation from the beginning, during his presentation at the 2013 WTO Academy, Simon Lester assumed that most probably the US would have won the case; or that would at least have brought the case away from non-discrimination (TBT 2.1) and hence it would have been decided only under necessity (TBT 2.2). ${ }^{214}$ The question that arises is should one look at the detrimental impact at the time of the enactment of a regulation or later - ie after it has been implemented? This may also relate to the accounts of the previous section concerning the assessment of the actual and future effects of a technical regulation.

Under TBT 2.2, the AB delves more into the design, architecture, and structure of the amended TR, as well as the nature of the risks of the non-fulfilment of its objective, and the gravity of the consequences arising from its non-fulfilment (and also criticises the panel for not doing so sufficiently):

...In this regard, we recall the interpretation of the phrase 'taking account of the risks non-fulfilment would create' set out above, namely, that 'taking account' calls for an active and meaningful consideration of the risks non-fulfilment would create' in the weighing and balancing under Article 2.2. At the same time, this requirement is also sufficiently flexible so as to be adaptable to the particularities of a given case. Thus, certain aspects of a technical regulation may be salient to 'taking account of the risks non-fulfilment would create' in a given case. (...)

However, the Panel did not consider the evidence and argumentation presented by Canada and Mexico to substantiate the connection between specific aspects of the design, architecture, and structure of the amended COOL measure, on the one hand, and the nature of the risks of the non-fulfilment of its objective or the gravity of the consequences arising from its non-fulfilment, on the other hand (my emphasis). ${ }^{215}$

Coming back to avoiding properly performing the TBT Article 2.2 necessity test, in US-COOL the AB did not find that the measure created an unnecessary obstacle to trade, because it found that it could not 'complete the analysis' under Article 2.2. ${ }^{216}$ In US-Clove Cigarettes the AB found discriminatory treatment between clove and menthol cigarettes as

\footnotetext{
${ }^{214}$ Lester (n 163).

215 US-COOL Article 21.5 (n 12) para 5.286.

${ }^{216}$ In this respect, see remarks of J Pauwelyn 'COOL ... But What Is Left Now for TBT Art. 2.2?' (International Economic Law and Policy Blog, 3 July 2012) < http://worldtradelaw.typepad. com/ielpblog/2012/07/cool-but-what-is-left-now-of-tbt-art-22.html > accessed 30 April 2015.
} 
it did in US-Tuna II (Mexico) between ETP and non-ETP tuna - hence a violation of TBT Article 2.1, but avoided assessing whether the conflicting regulations were 'more trade restrictive than necessary' pursuant to TBT 2.2. ${ }^{217}$ More recently, in US-COOL Article 21.5, the AB agreed with the compliance panel that the amended COOL violated TBT Article 2.1 in according discriminatory treatment to Canadian and Mexican livestock, and that the amended COOL was not more trade restrictive than necessary within the meaning of TBT Article 2.2, the measure making 'a considerable but, necessarily partial contribution' to its objective of providing consumer information on origin. ${ }^{218}$

In US-Clove Cigarettes, non-discrimination seems to be at the heart of the dispute. However, while being at odds with flavoured cigarettes and how they attract young smokers, the regulators included in the ban competing (mostly Indonesian) clove cigarettes, but not (mostly American) menthol cigarettes. ${ }^{219}$ In US-Tuna II (Mexico), non-discrimination was already less the crux of the dispute: Mexico was mainly complaining about the US not assigning the dolphin-safe label to (mainly Mexican) ETP tuna caught with a monitor on board, so 'setting on dolphins'. By finding differential treatment between ETP and non-ETP tuna, the AB, however, avoided addressing the root cause of this dispute. ${ }^{20}$ In US-COOL the matter of protectionism of US meat seems to be even less obvious - although, if the product origin labelling is supposedly a legitimate goal (as the AB found), then the problem with COOL is less one of discrimination (TBT Article 2.1), but rather whether the labelling requirements are more trade restrictive than necessary. ${ }^{221}$ The latter interpretive option - ie to assess the legitimate goal of the COOL against the COOL measures themselves - would have been closer not to the usual GATT/WTO necessity analysis, but to proportionality/balancing. Again, the parallel with the ECtHR MoA approach is far from perfect. Namely, in proportionality/balancing related to the MoA test, we do not really assess the measure itself to see

\footnotetext{
217 ibid.

218 US-COOL Article 21.5 (n 12) 5.279 and 5.284.

219 See S Lester, 'Free Trade and Tobacco: Thank You for Not Smoking (Foreign) Cigarettes' (2012) 49 Free Trade Bulletin, Cato Institute (15 August 2012) 1-2. See also Pauwelyn (n 216).

220 Pauwelyn (n 216).

221 'Ultimately, what the AB faulted COOL on was not so much origin-based discrimination but rather the fact that, irrespective of the origin of the meat, "the informational requirements imposed on upstream producers under the COOL measure are disproportionate as compared to the level of information communicated to consumers through the mandatory retail labels" (para 347). This "disproportionality" was, in turn, considered as not being "even-handed" which, in turn, was recognised as "arbitrary and unjustifiable discrimination" which, ultimately, led the AB to conclude that COOL's detrimental impact on imports did not "stem exclusively from a legitimate regulatory distinction" (para 349). Is this "disproportionality" really a matter of discrimination between Canadian and US meat? Or rather a question of necessity/proportionality of the measure as a whole?' Pauwelyn (n 216)
} 
if its restrictive effects exceed what is necessary to achieve the legitimate goal (taking account of the risks, etc), as seems to be the case in the USCOOL Article 21.5 ruling. We rather balance the legitimate goal itself, in assessing its legitimacy, against the restrictive effects of the measure. However, what may anyway be the potential reasons for the $\mathrm{AB}$ to rule as it did in the US-COOL Article 21.5 ruling?

I presume WTO panels and the AB could be less inspired to make an analysis of the necessity of a domestic regulatory measure because this would certainly involve rather more of very delicate political considerations, eg how to avoid protectionism but not undermine regulatory autonomy and the actual ability to promote national social imperatives. For one, the above rulings under the TBT suggest that the WTO tribunals, and especially the $\mathrm{AB}$, have probably considered that too much of a necessity investigation would appear as an inappropriate enquiry into government motivation, risk and other regulatory management, and simply too much intrusion into domestic policy space. That is, a proper balancing/proportionality test. This assumption could be confirmed by the comparable application of TBT Article 2.2 in the US-Tuna II (Mexico) panel report that was upheld by the $\mathrm{AB}$. That is, both tribunals did not delve too much into the legitimacy of the US measure per se in light of whether the corresponding requirements of the label were more trade restrictive than necessary. The panel decided that, in order to be deemed legitimate, a measure that aims at a particular end - to protect life or health, more exactly - need not be directed exclusively to endangered or depleted species or populations, within the meaning of TBT Article 2.2. ${ }^{222}$

The importance of the legitimate objective grounding the technical regulation in question, the extent to which such a legitimate objective could be scrutinised, and similar considerations were even more pronounced, and were actually crucial in the AB analysis in US-COOL Article 21.5. The section that follows is entirely consecrated to this analysis.

\section{4 'Whether the reasons presented by the government are relevant and sufficient, and whether there exists a pressing social need'}

As already mentioned, it appears from the TBT jurisprudence that, in order to be deemed legitimate, a regulation that aims at a particular end does not need be directed exclusively to that particular, narrow, end within the meaning of TBT Article 2.2. ${ }^{223}$ The importance of the legitimate objective grounding the TR in question and the extent to which such a legitimate objective could be assessed seem to be specifically underlined

${ }^{222}$ United States - Measures Concerning the Importation, Marketing and Sale of Tuna and Tuna Products [US-Tuna II (Mexico)]: Report of the Panel (15 September 2011) DS381, para 7.347; USTuna II (Mexico): Report of the Appellate Board (n 12) para 342.

223 US-Tuna II (Mexico): Report of the Appellate Board (n 12). 
by the terms 'importance to the Member implementing the regulation' introduced by the AB:

As we see it, the importance of the objective to the Member implementing the technical regulation at issue could inform the analysis under Article 2.2 in some capacity, to the extent it is reflected in the level considered appropriate by the Member to pursue the relevant objective, or the actual degree of contribution made by the technical regulation to its objective. For instance, where a Member chooses a high level of fulfilment for a technical regulation to contribute to its objective, this may be indicative of the importance this Member places on the fulfilment of that objective, and evidence pertaining to the importance a Member places on an objective might inform an assessment of the degree of contribution made by the technical regulation to its objective. Thus, we would ordinarily expect the gravity of the consequences arising from the nonfulfilment of the technical regulation's legitimate objective to correlate, at least to some extent, to the importance of the objective to the Member concerned (my emphasis). ${ }^{224}$

This approach is different from the relevant interpretive points in the GATT jurisprudence discussed above, for the AB seems to underline that members have certain discretion in considering what could constitute a legitimate objective of a particular regulation - ie the nature of the risks they seek to address and the gravity of the consequences arising from the non-fulfilment of the objective of their regulation. In this case, we might be closer to the unlocking of a proper balancing test mapping on proportionality stricto sensu. On the other hand, it is also possible that the above excerpt suggests that the permissible extent of regulatory discretion of members actually depends on the importance of an objective to a member, and less on its legitimacy. So, the latter should not be strictly assessed against the measure itself. Here we seem to be closer to the right of members to regulate at the levels they consider appropriate, hence farther from proportionality/balancing.

On the other hand, it is somehow different from the AB's previous line in the 2012 TBT trilogy. Namely, in these three cases, while not bringing too much into question the choice of what exactly could and could not be deemed as legitimate objectives important within the regulatory space of members, the $\mathrm{AB}$ did not expressly assume that states best know what could constitute an important legitimate objective, and that their regulations may themselves already contain elements pertaining to the nature and importance of the objective pursued.

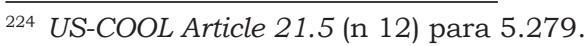


Unexpectedly enough, the approach of the AB in US-COOL Article 21.5 seems to somehow echo the principle of the evaluation of democratic necessity and proportionality - ie whether the reasons presented by the government are relevant and sufficient, and whether there exists a pressing social need - used in the MoA application of the ECtHR. ${ }^{225}$ However, here the $\mathrm{AB}$ seems to call the panels to perform, as part of a holistic analysis, the determination of flexibility - or discretion - that the WTO members have regarding one or another relevant TBT issue. By doing this, the $A B$ seems to suggest that domestic regulators should be, and normally are, perfectly able themselves to decide democratically what is an appropriate level of protection for them. That is, the AB emphasised that members have a certain 'margin of appreciation' in considering what could constitute a legitimate objective important for their nation. In this case, the $\mathrm{AB}$ is closer to the MoA as developed and used in Strasbourg. Alternatively, the AB possibly suggested that the extent of regulatory discretion could depend on the importance that the objective of relevant measures has for members. This interpretation seems to depart from the relevant interpretive points in the GATT as discussed above, as well as in the TBT jurisprudence. Yet, this is also different from the margin of appreciation concept discussed in this article - especially as developed by the Strasbourg Court.

\section{Concluding remarks}

The WTO TBT Agreement aims at striking an equilibrium between the trade and non-trade goals of members, and at offering a legal framework for state regulations protecting human and plant life and health, consumer interests, the environment, and the like. In most of the jurisprudence under the TBT, WTO tribunals, and especially the Appellate Body, while not mentioning it expressly, seem to enquire too much into the discriminatory effects of the domestic regulation in question under TBT Article 2.1, while avoiding scrutinising too much the legitimacy and the management of the regulation under TBT Article 2.2. In its latest relevant ruling, US-COOL Article 21.5, the Appellate Body appears to spell out such a tendency. In addition, in this case, the Appellate Body clearly raised the concept of margin of appreciation - at the international level, an interpretative development and perquisite of the European Court of Human Rights.

The margin of appreciation concept maps onto a strict proportionality analysis. While proportionality stricto sensu relates to the proportionality of the means related to the ends, and the balancing between two values deemed equal, the necessity test means that the ranking is a priori

$\overline{225}$ See eg Marckx (n 56) para 41; Handyside (n 32) paras 48-49. 
fixed in favour of one value. A few points should be specified here. Proportionality stricto sensu, while it may be seen as even more controversial than the necessity test, is not exactly about balancing what the regulation achieves (ie the 'importance' of the objective) versus its costs - in the WTO, the costs to trade (so, its trade restrictiveness). It is rather about comparing the legitimacy of the objective of a measure (the legitimacy of the objective defending non-trade interests - so, non-trade values) with the regulation itself (its costs to trade, so trade values). That is, in my view, in trade law, proportionality stricto sensu would be balancing the legitimacy of a measure's trade restrictiveness against its actual and potential trade restrictiveness. On the other hand, the assessment of the margin of appreciation as held in Strasbourg should primarily depend on weighing the importance of the sovereign (non-human rights) interests of parties to the Convention, such as domestic security, and of rights (human rights) protected by the ECHR. In my opinion, there could be no such delimitation within the trade regime. Indeed, both main interests of the parties and the rights protected by the WTO treaties are about free trade: ie trade interests and trade rights. Also, and in relation to this, it has been clearly demonstrated in my paper that the role of the GATT/ WTO tribunals is the enforcement of the mutual - trade - obligations of the members. However, according to the principle of subsidiarity - one of the core principles related to the concept of margin of appreciation - the supervisory meaning of the ECHR and the related function of the Strasbourg Court is the effective protection of human rights rather than the enforcement of mutual obligations between parties to the Convention. That is, the latter should not be interpreted restrictively in deference to sovereign legislative authority. These points obviously constitute one of the reasons why the WTO Appellate Body reference to the margin of appreciation concept in the US-COOL Article 21.5 judgment attracts so much attention.

As I have demonstrated in the analysis of WTO case law throughout this paper, under GATT relevant jurisprudence, WTO judges applied a necessity test properly speaking. Until the US-COOL Article 21.5 decision, under the TBT, WTO adjudicators, and especially the Appellate Body, added nuances to the necessity test with considerations related to the right of WTO members to regulate in order to set their own level of protection.

In the US-COOL Article 21.5 ruling, however, the Appellate Body appeared to consider members' discretion inherent in the design and application of their regulations. Yet, the Appellate Body refused to expressly comment on the reasons for introducing some sort of balancing in its reasoning, as well as on its avoidance to scrutinise the management of the regulation in question under the necessity test of TBT Article 2.2. 
Overall, the interpretative developments within world trade adjudication, relevant for the margin of appreciation concept, could be summarised as follows:

- GATT panels before the inception of the WTO: a strict necessity test where virtually no balancing took place at all - ranking was clearly fixed in favour of trade liberalisation values;

- WTO DSB jurisprudence under the GATT in 'trade and debate...': a flexible necessity test where some degree of balancing was taking place - the ranking was fixed rather in favour of trade and market competition values, but some room for non-trade values, especially health and the environment, was granted on exceptional grounds; 226

- Recent WTO DSB jurisprudence under the TBT: more balancing, a very lax (I would say, 'impossible to fail') necessity test, much more deference to the regulator in terms of legitimacy of the aim of the measures in question;

- US-COOL Article 21.5: the same very lax necessity test, even more deference to the regulator in terms of legitimacy of the aim of the measures, plus an appeal to the margin of appreciation concept.

The latest interpretative development in US-COOL Article 21.5, namely the WTO Appellate Body's plea for the margin of appreciation concept may have interesting developments for future WTO cases. At least two scenarios are possible. Either the Appellate Body has suggested in this ruling that members have certain discretion in considering what could constitute a legitimate objective of a particular regulation. In this case, in assessing the legitimacy of the objective of a measure against the measure itself, we might be closer to the unlocking of a proper balancing test mapping on proportionality stricto sensu. Or the Appellate Body's interpretation implies that the permissible degree of regulatory discretion of members actually rather depends on the importance of the objective to a member, and not - or less - on its legitimacy, so the latter should not be placed under strict scrutiny. Here we seem to be closer to the right of members to regulate at the levels they consider appropriate - the inter-

\footnotetext{
${ }^{226}$ Please note that I am not talking here at all about the recent WTO case EC-Seals for the main reason that, taking into account the parallel with the ECHR interpretation of the margin of appreciation, and consensus on values constituting part of its factors, it would be very confusing to compare the latter WTO DSB decision. Indeed, in the EC-Seals case, the $\mathrm{DSB}$, and especially the AB, ruled in what could be judged the opposite and somehow embarrassing way compared to the ECHR appreciation of an inter-state consensus on values, as for instance, in the Handyside case discussed in the first section. That is, in EC-Seals, the WTO DSB somehow affirmed a sort of universal value of public morals. In Handyside, recall that the ECtHR said that even within Europe it is difficult to find a common denominator of public morals.
} 
pretations proper to the established GATT/TBT jurisprudence, and hence farther from proportionality/balancing.

Notably, as explained in the paper, under the ECtHR's application of margin of appreciation, a treatment that is different for some categories in the exercise of Convention rights must be deemed discriminatory if it is proved unnecessary. So, it could be presumed that if, in future, WTO judges wanted to use under the TBT the concept from Strasbourg, they would need to start from the necessity test (Article 2.2), and then move on to the non-discrimination analysis (Article 2.1). That is, in theory, in order to continue with non-discrimination, the tribunals would first have to decide that the measure is unnecessary - something that in practice the WTO Appellate Body seems to avoid at any cost.

As a last remark, as well as perhaps an issue for future research, I would like to note that, as explained at the beginning of the paper, most of the interpretative factors, fundamental principles and values underlying the concept of margin of appreciation as developed by the Strasbourg Court are expressly or tacitly Eurocentric. Take for instance the standard of European consensus as used in the related jurisprudence of the ECtHR. Therefore, any endeavour to use the concept of margin of appreciation in other legal regimes would involve a sort of transplant of relevant Eurocentric values, concepts, standards and principles. Without doing so, it would be impossible to use this concept properly. But by doing so, in the particular case of the WTO, we risk building just another hegemonic project of the type 'GATT-before-1995' inside the world trade regime. Such a 'transplant' from ECtHR to WTO jurisprudence might also provoke a 'rejection', or an 'anti-body reaction'. 